Prepared in cooperation with the Department of the Navy, Naval Facilities Engineering Command, Northwest

\title{
Analysis of Groundwater Response to Tidal Fluctuations, Operable Unit 1, Naval Base Kitsap, Keyport, Washington
}

Open-File Report 2019-1098 


\section{Analysis of Groundwater Response to Tidal Fluctuations, Operable Unit 1, Naval Base Kitsap, Keyport, Washington}

By Chad C. Opatz and Richard S. Dinicola

Prepared in cooperation with the Department of the Navy, Naval Facilities Engineering Command, Northwest

Open-File Report 2019-1098

U.S. Department of the Interior

U.S. Geological Survey 


\section{U.S. Department of the Interior \\ DAVID BERNHARDT, Secretary}

\section{U.S. Geological Survey James F. Reilly, Director}

U.S. Geological Survey, Reston, Virginia: 2019

For more information on the USGS-the Federal source for science about the Earth, its natural and living resources, natural hazards, and the environment-visit https://www.usgs.gov/ or call 1-888-ASK-USGS (1-888-275-8747).

For an overview of USGS information products, including maps, imagery, and publications, visit https://store.usgs.gov/.

Any use of trade, firm, or product names is for descriptive purposes only and does not imply endorsement by the U.S. Government.

Although this information product, for the most part, is in the public domain, it also may contain copyrighted materials as noted in the text. Permission to reproduce copyrighted items must be secured from the copyright owner.

Suggested citation:

Opatz, C.C., and Dinicola, R.S., 2019, Analysis of groundwater response to tidal fluctuations, Operable Unit 1, Naval Base Kitsap, Keyport, Washington: U.S. Geological Survey Open-File Report 2019-1098, 36 p., https://doi.org/10.3133/ofr20191098.

ISSN 2331-1258 (online) 


\section{Contents}

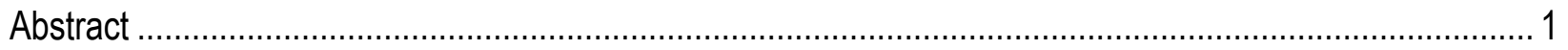

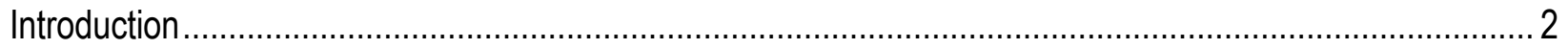

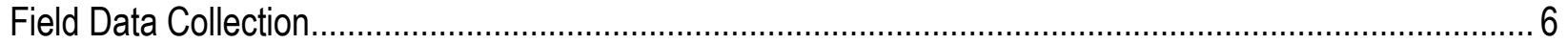

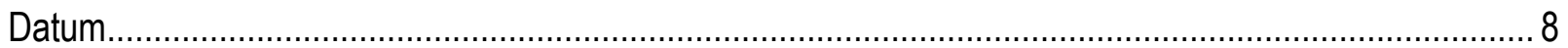

Groundwater Sensor Deployment and Vertical Water-Quality Profiling ............................................. 9

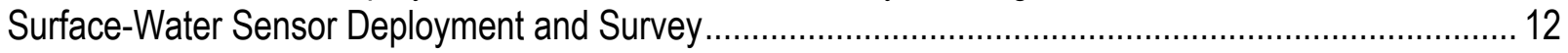

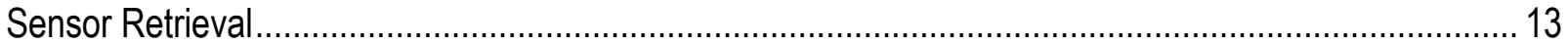

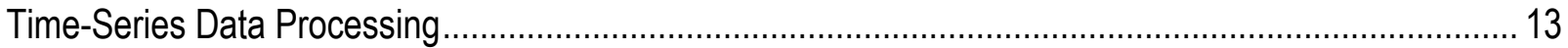

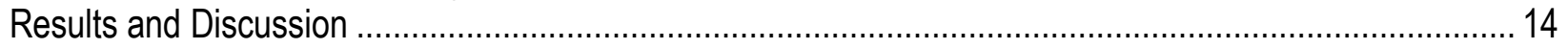

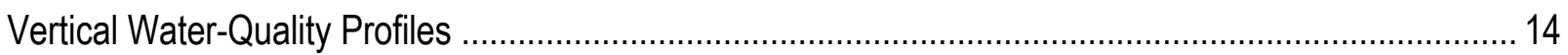

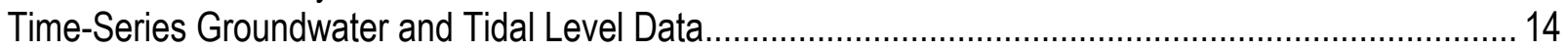

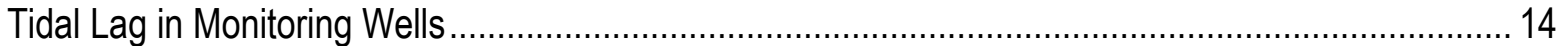

Surface-Water Levels and Specific Conductance in Water Bodies Surrounding Operable Unit 1.......... 16

Optimal Depths and Time for Groundwater Sampling .................................................................... 16

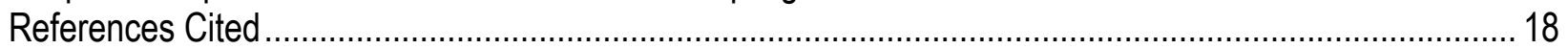




\section{Figures}

Figure 1. Map showing location of monitoring sites near Operable Unit 1 (OU1), Naval Base Kitsap, in Keyport, Washington .

Figure 2. Map showing location of monitoring sites near Operable Unit 1 (OU1), Naval Base Kitsap, in

Keyport, Washington ...

Figure 3. Graph showing groundwater levels in monitoring well MW1-38 and tidal levels of Tide Flats and Liberty Bay at Operation Unit 1 of Naval Base Kitsap, in Keyport, Washington, July 12August 9, 2018.

Figure 4. Graph showing groundwater levels in monitoring well MW1-39 and tidal levels of Tide Flats and Liberty Bay at Operable Unit 1 of Naval Base Kitsap, in Keyport, Washington, July 12August 9, 2018

Figure 5. Graph showing groundwater levels in monitoring well MW1-9 and tidal levels of Tide Flats and Liberty Bay at Operable Unit 1 of Naval Base Kitsap, in Keyport, Washington, July 12August 9, 2018

Figure 6. Graph showing groundwater levels in monitoring well MW1-29 and tidal levels of Tide Flats and Liberty Bay at Operable Unit 1 of Naval Base Kitsap, in Keyport, Washington, July 12 ugust 9,2018

Figure 7. Graph showing groundwater levels in monitoring well MW1-25 and tidal levels of Tide Flats and Liberty Bay at Operable Unit 1 of Naval Base Kitsap, in Keyport, Washington, July 12August 9, 2018

Figure 8. Graph showing groundwater levels in monitoring well $1 \mathrm{MW}-4$ and tidal levels of Tide Flats and Liberty Bay at Operable Unit 1 of Naval Base Kitsap, in Keyport, Washington, July 12August 9, 2018.

Figure 9. Graph showing groundwater levels in monitoring well MW1-60 and tidal levels of Tide Flats and Liberty Bay at Operable Unit 1 of Naval Base Kitsap, in Keyport, Washington, July 12August 9, 2018

Figure 10. Graph showing groundwater levels in monitoring well MW1-43 and tidal levels of Tide Flats and Liberty Bay at Operable Unit 1 of Naval Base Kitsap, in Keyport, Washington, July 12August 9, 2018

Figure 11. Graph showing groundwater levels in monitoring well $1 \mathrm{MW}-1$ and tidal levels of Tide Flats and Liberty Bay at Operable Unit 1 of Naval Base Kitsap, in Keyport, Washington, July 12August 9, 2018

Figure 12. Graph showing groundwater levels in monitoring well MW1-2 and tidal levels of Tide Flats and Liberty Bay at Operable Unit 1 of Naval Base Kitsap, in Keyport, Washington, July 12August 9, 2018

Figure 13. Graph showing groundwater levels in monitoring well MW1-45 and tidal levels of Tide Flats and Liberty Bay at Operable Unit 1 of Naval Base Kitsap, in Keyport, Washington, July 12August 9, 2018.

Figure 14. Graph showing groundwater levels in monitoring well MW1-47 and tidal levels of Tide Flats and Liberty Bay at Operable Unit 1 of Naval Base Kitsap, in Keyport, Washington, July 12August 9, 2018

Figure 15. Graph showing groundwater levels in monitoring wells MW1-41, MW1-50, MW1-51, P1-10, MW1-20, and MW1-10, and tidal levels of Tide Flats and Liberty Bay at Operable Unit 1 of Naval Base Kitsap, in Keyport, Washington, July 12-August 9, 2018 
Figure 16. Representative graph showing immediate tidal response well group using monitoring well MW1-38 as an example at Operable Unit 1 of Naval Base Kitsap, in Keyport, Washington, July 12August 14, 2018 ....

Figure 17. Representative graph showing $2-5$ hour tidal response well group using monitoring well MW1-25 for an example at Operable Unit 1 of Naval Base Kitsap, in Keyport, Washington, July 12August 14, 2018

Figure 18. Representative graph showing minimal tidal response well group using monitoring well MW1-10 as an example at Operable Unit 1 of Naval Base Kitsap, in Keyport, Washington, July 12August 14, 2018

Figure 19. Graph showing surface-water levels measured in Marsh Pond, Shallow Lagoon, Marsh Creek, Tide Flats, and Liberty Bay at Operable Unit 1 of Naval Base Kitsap, in Keyport, Washington, July 12-August 8, 2018

Figure 20. Graph showing specific conductance measured in Marsh Pond, Shallow Lagoon, Tide Flats, and Liberty Bay at Operable Unit 1 of Naval Base Kitsap, in Keyport, Washington, July 12-August 8,2018 ........

\section{Tables}

Table 1. Characteristics of monitoring wells at Operable Unit 1 of Naval Base Kitsap, in Keyport, Washington.

Table 2. Characteristics of surface-water monitoring sites at Operable Unit 1 of Naval Base Kitsap, in

Keyport, Washington

Table .3 Water levels measured during deployment and retrieval of the pressure transducers and conductance-temperature-depth sensors in 19 monitoring wells at Operable Unit 1 of Naval Base Kitsap, in Keyport, Washington, July 11-August 9, 2018

Table 4. Vertical water-quality profile measurements in selected monitoring wells at Operation Unit 1 of Naval Base Kitsap, in Keyport, Washington. July 11-August 8, 2018

Table 5. Water levels measured during deployment and retrieval of conductance-temperature-depth sensors at surface-water sites bounding Operation Unit 1 of Naval Base Kitsap, in Keyport, Washington, July 11-August 9, 2018 .

Table 6. Ranges of time differences (tidal lags) between a minimum groundwater level altitude in a monitoring well and the preceding low-low tide calculated from data collected at Operable Unit 1 of Naval Base Kitsap, in Keyport, Washington. July 12-August 8, 2018

\section{Conversion Factors}

U.S. customary units to International System of Units

\begin{tabular}{|c|c|c|}
\hline Multiply & By & To obtain \\
\hline \multicolumn{3}{|c|}{ Length } \\
\hline foot $(\mathrm{ft})$ & 0.3048 & meter $(\mathrm{m})$ \\
\hline
\end{tabular}

Temperature in degrees Celsius $\left({ }^{\circ} \mathrm{C}\right)$ may be converted to degrees Fahrenheit $\left({ }^{\circ} \mathrm{F}\right)$ as follows: ${ }^{\circ} \mathrm{F}=\left(1.8 \times{ }^{\circ} \mathrm{C}\right)+32$.

\section{Datum}

Vertical coordinate information is referenced to the North American Vertical Datum of 1988 (NAVD 88).

Horizontal coordinate information is referenced to the North American Datum of 1983 (NAD 83).

Altitude and level, as used in this report, both refer to distance above the vertical datum. 


\section{Supplemental Information}

Specific conductance is given in microsiemens per centimeter at 25 degrees Celsius $\left(\mu \mathrm{S} / \mathrm{cm}\right.$ at $\left.25^{\circ} \mathrm{C}\right)$.

\section{Abbreviations}

CTD conductance-temperature-depth sensor

MP Measuring Point

NBK Naval Base Kitsap

OU $1 \quad$ Operable Unit 1

PT pressure transducer

TOC top of casing

USGS U.S. Geological Survey

VOC

volatile organic compound 


\title{
Analysis of Groundwater Response to Tidal Fluctuations, Operable Unit 1, Naval Base Kitsap, Keyport, Washington
}

\author{
By Chad Opatz and Richard S. Dinicola
}

\begin{abstract}
Chlorinated volatile organic compounds have affected groundwater beneath a former 9acre landfill at Operable Unit 1 (OU 1) of Naval Base Kitsap (NBK) Keyport, in Keyport, Washington. The landfill was the primary disposal area for domestic and industrial waste generated by NBK Keyport from the 1930s through 1973. Naval Facilities Engineering Command Northwest, in conjunction with the Environmental Protection Agency, Washington State Department of Ecology, and the Suquamish Tribe, is charged with collecting necessary data to monitor the contamination left in place and to ensure that the site does not pose a risk to human health or the environment.

To support these efforts, refined information was collected on how groundwater levels throughout OU 1 respond to tidal fluctuations at this nearshore site adjacent to Liberty Bay, an inlet of Puget Sound. The information was analyzed to determine the optimal times during the semidiurnal and the neap-spring tidal cycles to sample groundwater for contaminants associated with fresh groundwater originating from OU 1. The optimal times for sampling are presumed to be when fresh groundwater flowing seaward is least impeded by elevated tides, and those times are related to predicted tide levels by tidal lags, the durations between low tides, and corresponding low groundwater levels. Discrete groundwater-specific conductance data also were collected to determine if a seawater/freshwater interface was present at any of the monitoring wells, and to inform decisions on the depth at which groundwater should be sampled in existing wells.

Groundwater and surface-water levels were monitored at 19 monitoring wells and five adjacent surface-water sites. Specific conductance was monitored in each surface-water site. All time-series data parameters were collected every 15 minutes during a 4-week duration to measure how nearshore groundwater responds to tidal forcing. Time-series data were collected from July 12, 2018, to August 8, 2018, a period that included neap and spring tides. Vertical water-quality profiles were measured once in the screened interval of nine selected monitoring wells. The profiles included measurements at the top, middle, and bottom of each saturated screen interval.

Tidal lag times were determined relative to tidal levels in Liberty Bay (rather than in the more nearby Tide Flats) because the predicted tides for the Poulsbo, Washington Station (National Oceanic and Atmospheric Administration [NOAA] Station 9445719) that are used to schedule groundwater sampling represent open-water conditions in the area; a sill that separates Dogfish Bay from the Tide Flats clearly affects the timing and magnitude of low-low tides in the
\end{abstract}


Tide Flats. Calculated tidal lag times were divided into three general groups: (1) wells where groundwater responded to tidal level changes immediately, (2) wells where groundwater responded to tidal level changes within about 2-5 hours, and (3) wells where groundwater had minimal response to tidal level changes. Groundwater levels in the middle group of wells primarily responded in concert with tidal level changes in the Tide Flats rather than tidal level changes in Liberty Bay.

An intended sampling depth refinement based on an assessment of transient seawater intrusion was not completed because of a failure to collect specific-conductance time-series data in select wells. Instead, discrete specific-conductance data from this and prior studies were evaluated to determine that the midpoint of well screens in OU 1 wells can be assumed to be a reasonably representative of undiluted groundwater. When sampling during spring (rather than neap) tides (as has generally been the standard practice at OU 1), the optimal time to sample the monitoring wells influenced by tides would be to add the tidal lags presented in this report to the time of the predicted low-low tide for Liberty Bay as measured at NOAA Station 9445719 at Poulsbo, Washington. Sampling schedules for the six wells where groundwater levels were only minimally influenced by tide changes should not be constrained by tidal conditions.

\section{Introduction}

Naval Base Kitsap (NBK) Keyport is on a small peninsula in Kitsap County, Washington, in an inlet of Puget Sound called Liberty Bay (fig. 1). Chlorinated volatile organic compounds (VOCs) have affected groundwater beneath a former 9-acre landfill at Operable Unit 1 (OU 1) that was constructed in a marsh west of the narrow strip of land connecting the peninsula to the mainland. The landfill was the primary disposal area for domestic and industrial waste generated by NBK Keyport from the 1930s through 1973. Remediation efforts at OU 1 are ongoing, and a long-term groundwater monitoring program is in place. 


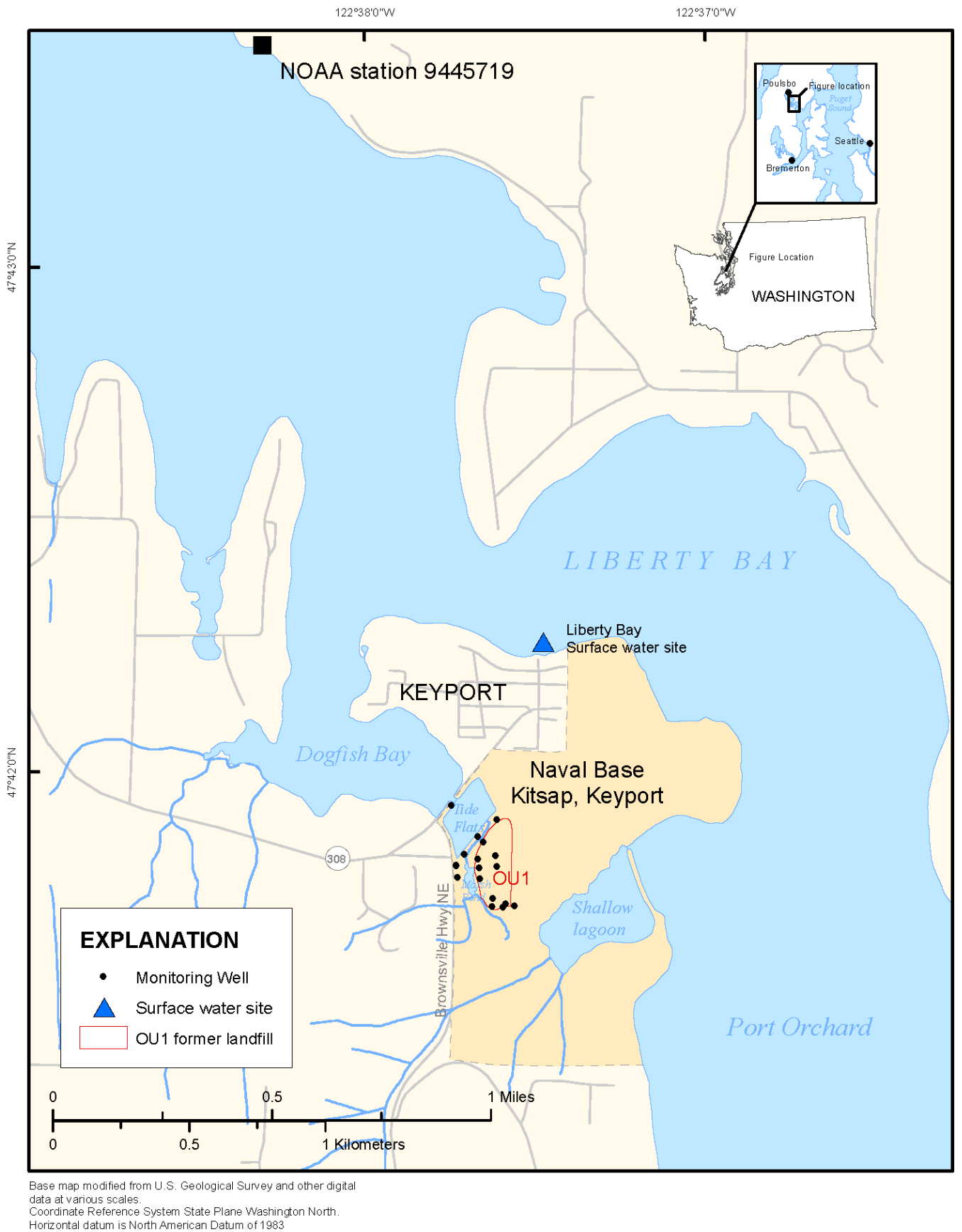

Figure 1. Map showing location of monitoring sites near Operable Unit 1 (OU1), Naval Base Kitsap, in Keyport, Washington. NOAA, National Oceanic and Atmospheric Administration 
Naval Facilities Engineering Command Northwest, in conjunction with the U.S, Environmental protection Agency (EPA), Washington state Department of Ecology (Ecology), and the Suquamish Tribe, is charged with collecting necessary data to monitor the contamination left in place and ensuring that the site does not pose a risk to human health or the environment. To support those efforts, these organizations need refined information on how groundwater levels throughout OU 1 respond to tidal fluctuations to determine the optimal times during the semidiurnal and the neap-spring tidal cycle to sample groundwater for contaminants associated with fresh groundwater originating from $\mathrm{OU} 1$. The optimal times for sampling are presumed to be when freshwater flowing seaward is least impeded by elevated tides, and those times are related to predicted tide levels by tidal lags, the durations between low tides, and corresponding low groundwater levels. Specifically, the groundwater monitoring plan needs to consider the timing of minimum groundwater levels following low tides as well as the relative proportions of fresh groundwater and seawater in wells throughout the semidiurnal and longer-term spring-neap tidal cycles. This information will allow for the collection of groundwater samples and measurement of water levels that are least affected by groundwater-seawater interactions.

There are five tidally influenced surface-water features surrounding the strip of land connecting the peninsula to the mainland that potentially influence groundwater levels and local flow directions at OU 1 (fig. 2); the connected open-waters of (1) Dogfish Bay/Liberty Bay/Port Orchard Bay, (2) Tide Flats, (3) Marsh Creek, (4) Marsh Pond, and (5) Shallow Lagoon. The timing and magnitude of water-level fluctuations in the latter four features are primarily controlled by semidiurnal tidal fluctuations in the open waters of Dogfish Bay/Liberty Bay/Port Orchard Bay (hereinafter referred to as Liberty Bay), as modified by flow constrictions at sills separating Liberty Bay and the Tide Flats and Shallow Lagoon, and by a tide gate at the outlet of Marsh Creek where it discharges to the Tide Flats. Of these five surface-water features, predicted tides are available for the open waters of Liberty Bay only (National Oceanic and Atmospheric Administration [NOAA] Station 9445719, Poulsbo, Washington) that can be used as a basis for scheduling sampling activities. Although the surface-water data for the site was collected off the north shore of Keyport peninsula in Liberty Bay, water levels in the unconstricted open-water sites of Port Orchard Bay, Liberty Bay, and Dogfish Bay are expected to be nearly identical because there are no hydraulic barriers to flow between these each of water bodies. 


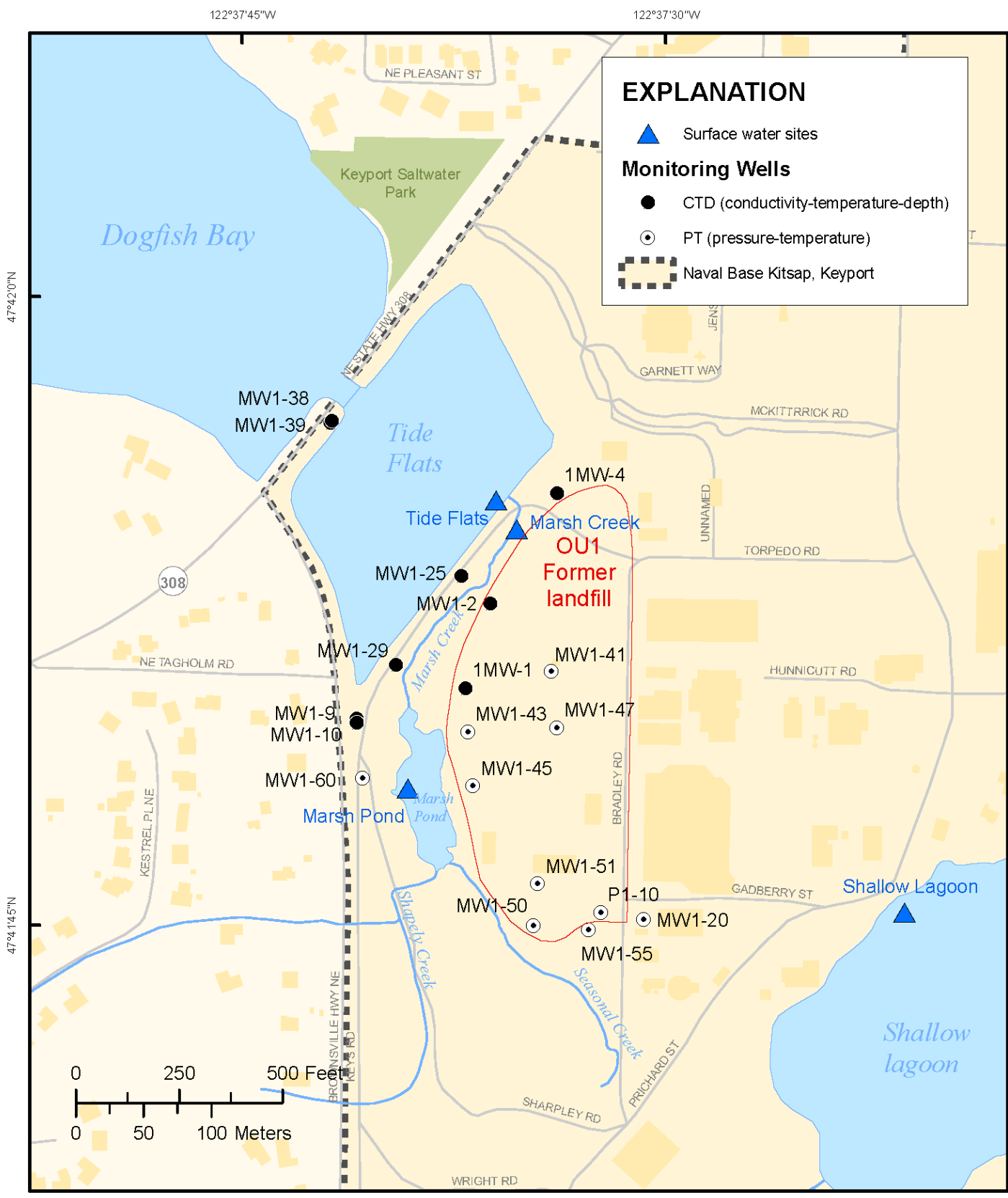

Base map modified from U.S. Geological Survey and other digital data at 1:15,000. Coordnate Reference System State Plane
Washington North. Horizontal daturn is North American D otum

Figure 2. Map showing location of monitoring sites near Operable Unit 1 (OU1), Naval Base Kitsap, in Keyport, Washington. 


\section{Objective and Scope}

This report describes the results of a tidal lag study at OU 1 that was done to better understand nearshore groundwater-seawater interactions, optimally schedule groundwater sampling times for different wells, and to inform a parallel groundwater modeling effort at the site. To help meet these objectives, water levels in 19 existing groundwater monitoring wells and the five surface-water features of interest were continuously monitored for about 3 weeks over multiple semidiurnal tidal cycles. These time-series data, which also included specific conductance at the surface-water sites, were collected from July 12, 2018, to August 8, 2018, a period that included neap and higher-amplitude spring tides. Additionally, a vertical profile of specific conductance was measured once in the screened interval of selected monitored wells to determine if a freshwater/saltwater interface was present. All time-series data collected were corrected for barometric pressure effects, quality-assured, and published in a U.S. Geological Survey (USGS) ScienceBase data release (https://doi.org/10.5066/P9FB3KLK; Opatz, 2019).

\section{Field Data Collection}

From July 11 th through July 17, 2018, a USGS field team installed instrumentation at groundwater and surface-water monitoring sites. Ten vented pressure transducers (hereinafter referred to as PTs) and nine non-vented conductance-temperature-depth sensors (hereinafter referred to as CTDs) were deployed in 19 OU 1 monitoring wells (table 1). Additionally, five non-vented CTDs were deployed at the five surface-water sites of interest (table 2). All sensors operated from July 12, 2018 to August 8, 2018. The pressure transducer in well MW1-55 failed to log any data, and conductance was not logged by any of the CTDs in the monitoring wells because of a programming error. The predicted tides for that period at nearby Liberty Bay at Poulsbo, Washington (NOAA Station 9445719) included a relatively large tidal-range spring tide around July 14, 2018, and a moderate tidal-range neap tide around July 27, 2018. 
Table 1. Characteristics of monitoring wells at Operable Unit 1 of Naval Base Kitsap, in Keyport, Washington.

[Sensor type: CTD, conductance-temperature-depth; PT, pressure transducer. CTD has a non-vented pressure transducer and PT is a vented pressure transducer. Abbreviations: bgs, below ground surface; NAVD 88, North American Vertical Datum of 1988; USGS, U.S. Geological Survey]

\begin{tabular}{lccrc}
\hline $\begin{array}{c}\text { Monitoring } \\
\text { well identifier }\end{array}$ & USGS site identification & $\begin{array}{c}\text { Measuring Point altitude } \\
\text { (feet above NAVD 88) }\end{array}$ & $\begin{array}{c}\text { Screened interval } \\
\text { (feet bgs) }\end{array}$ & $\begin{array}{c}\text { Sensor } \\
\text { type }\end{array}$ \\
\hline 1MW-1 & 474151122373201 & 13.35 & $5.5-15.5$ & CTD \\
1MW-4 & 474156122373201 & 15.71 & $15-25$ & CTD \\
MW1-2 & 474153122373101 & 15.16 & $12.5-17.5$ & CTD \\
MW1-9 & 474150122374001 & 15.34 & $48.5-58.5$ & CTD \\
MW1-10 & 474150122374101 & 15.31 & $4-14$ & CTD \\
MW1-20 & 474145122372501 & 13.75 & $10-15$ & PT \\
MW1-25 & 474154122373201 & 15.27 & $38-48$ & CTD \\
MW1-29 & 474152122373501 & 16.05 & $31.5-36.5$ & CTD \\
MW1-38 & 474156122373701 & 13.23 & $44-49$ & CTD \\
MW1-39 & 474157122373701 & 13.22 & $27.7-32.7$ & CTD \\
MW1-41 & 474152122372901 & 18.51 & $5-15$ & PT \\
MW1-43 & 474150122373601 & 12.69 & $14.6-24.6$ & PT \\
MW1-45 & 474149122373601 & 12.99 & $14.7-24.7$ & PT \\
MW1-47 & 474150122373301 & 16.44 & $14.7-24.7$ & PT \\
MW1-50 & 474146122373401 & 16.75 & $7.5-17.5$ & PT \\
MW1-51 & 474147122373001 & 17.23 & $12.8-22.8$ & PT \\
${ }^{1}$ MW1-55 & 474146122373301 & 15.60 & $29.9-39.9$ & PT \\
MW1-60 & 474149122374001 & 18.01 & $18.2-28.2$ & PT \\
P1-10 & 474145122372601 & 15.16 & $10-15$ & PT \\
\hline
\end{tabular}

${ }^{1} \mathrm{PT}$ deployed in MW1-55 failed to log data.

A vented pressure transducer has an air vent tube that is open to atmospheric pressure at the land surface. The mechanism in the transducer is designed to compensate for the effects of atmospheric pressure on the water level by automatically subtracting the air pressure in the vent tube. This assumes that the air pressure at the well head and at the water surface are in equilibrium. The water pressure measured by the transducer, therefore, is assumed to be equal to what the water pressure would be in a vacuum.

The CTDs measure absolute pressure; that is, the pressure of the water column above the sensor plus the pressure of the air at the water surface. After data were collected, atmospheric pressure measured at OU 1 was subtracted from absolute pressure measurements from the CTDs to calculate water-level data that are equivalent to data from the vented transducers. Rasmussen and Crawford (1997) provide details on vented and non-vented transducers and appropriate uses of data collected from these devices. 
Table 2. Characteristics of surface-water monitoring sites at Operable Unit 1 of Naval Base Kitsap, in Keyport, Washington.

[Site location: Coordinate locations of surface-water monitoring sites are referenced to the North American Datum of 1983. Abbreviations: CTD, conductance-temperature-depth sensor; NAVD 88, North American Vertical Datum of 1988]

\begin{tabular}{|c|c|c|}
\hline $\begin{array}{l}\text { Surface-water site } \\
\text { identifier }\end{array}$ & $\begin{array}{c}\text { Site location } \\
\text { (latitude/longitude) }\end{array}$ & Site description \\
\hline Marsh Pond & $\begin{array}{l}47.696799 \mathrm{~N} \\
122.627365 \mathrm{~W}\end{array}$ & $\begin{array}{l}\text { CTD secured to driven-in fence post positioned } \\
\text { approximately } 30 \text { feet off end of Marsh Creek dock } \\
\text { across Keyes Road from MW1-60. Surveyed in } \\
\text { using MW1-60 as reference location. }\end{array}$ \\
\hline Marsh Creek & $\begin{array}{l}47.698533 \mathrm{~N} \\
122.626356 \mathrm{~W}\end{array}$ & $\begin{array}{l}\text { CTD secured to driven-in fence post positioned mid- } \\
\text { channel approximately } 40 \text { feet upstream of Keyes } \\
\text { Road culvert. Surveyed in using } 1 \mathrm{MW}-4 \text { as reference } \\
\text { location. }\end{array}$ \\
\hline Tide Flats & $\begin{array}{l}47.698723 \mathrm{~N} \\
122.626563 \mathrm{~W}\end{array}$ & $\begin{array}{l}\text { CTD secured to driven-in 3-feet steel stake positioned } \\
\text { approximately } 15 \text { feet from tide gate south-east } \\
\text { shore-line of Tide Flats. Surveyed in using 1MW-4 } \\
\text { as reference location. }\end{array}$ \\
\hline Shallow Lagoon & $\begin{array}{l}47.696054 \mathrm{~N} \\
122.622453 \mathrm{~W}\end{array}$ & $\begin{array}{l}\text { CTD positioned approximately } 30 \text { feet offshore } \\
\text { anchored with cinder block. Buoy attached to cinder } \\
\text { block with } 20 \text { feet of rope for identification and } \\
\text { recovery. Surveyed in using P1-10 as reference } \\
\text { location. }\end{array}$ \\
\hline Liberty Bay & $\begin{array}{l}47.704695 \mathrm{~N} \\
122.623899 \mathrm{~W}\end{array}$ & $\begin{array}{l}\text { CTD positioned adjacent to public dock piling secured } \\
\text { to cinder block with affixed U.S. Geological Survey } \\
\text { "Gauging Station" identification plate. Surveyed in } \\
\text { using Washington State Department of } \\
\text { Transportation mark on State Route } 308 \text { at NAVD } \\
88 \text { altitude of } 13.064 \text { feet. }\end{array}$ \\
\hline
\end{tabular}

\section{Datum}

The vertical datum used for this report is the North American Vertical Datum of 1988 referenced for nearly all monitoring well top of casing (TOC) altitudes. Past reported information on well altitudes used a mix of NAVD 88 and mean-sea level. All wells included in this tidal lag study were resurveyed by the Navy to the NAVD 88 datum in September 2018 to remedy TOC altitude discrepancies.

Predicted tides for NOAA station 9445719 are referenced to mean-low-low-water. To approximately convert these tides to a NAVD 88 datum, we calculated the differences between the daily high and low tides predicted by NOAA and measured for this study at the Liberty Bay surface water site from July 11, 2018 to August 09, 2018 A mean difference of 3.00 feet was calculated, and that offset was applied to predicted tidal data where applicable to allow direct comparison of tidal levels to groundwater levels referenced to the same NAVD 88 datum. 


\section{Groundwater Sensor Deployment and Vertical Water-Quality Profiling}

All sensors were calibrated and checked for accuracy in the USGS Field Services Unit prior to deployment. A two-point depth calibration check of the transducer was performed, along with a three-point specific-conductance calibration check on the CTDs using 250-, 12,890-, and 50,000 -microsiemens-per-centimeter $(\mu \mathrm{S} / \mathrm{cm})$ standards. The range of specific conductance standards used in the calibration check was based on specific conductance expected in nearshore groundwater monitoring wells.

Depth-to-water measurements were collected from all wells using an electric tape (table 3). A dedicated, calibrated field CTD sensor was used to measure vertical profiles in the monitoring wells. The vertical profiles of water quality within the screened monitoring well intervals were measured by lowering the field CTD to the bottom of the interval, recording the measurements once stabilized, and repeating the measurements in the middle of and at the top of the saturated column. Tidal condition (ebbing or flooding) during well profile measurements varied over the 3 days of field deployment (table 4). After vertical profiles were measured, the deployed CTDs were lowered and secured at approximately mid-depth of the well-screen interval for each monitoring well. Because of the potential for rapid tidally induced water-level changes in some monitoring wells, a final manual depth-to-water measurement was made immediately before the first scheduled water-level measurement recorded by deployed CTD as a quality-assurance check. Each CTD was programmed to record temperature and depth data at 15minute intervals. The CTDs were originally intended to also record specific conductance data at 15-minute intervals, but that program was not correctly implemented. 
Table .3 Water levels measured during deployment and retrieval of the pressure transducers and conductance-temperature-depth sensors in 19 monitoring wells at Operable Unit 1 of Naval Base Kitsap, in Keyport, Washington, July 11-August 9, 2018.

[Abbreviation: NAVD 88, North American Vertical Datum of 1988]

\begin{tabular}{|c|c|c|c|}
\hline $\begin{array}{c}\text { Monitoring } \\
\text { well } \\
\text { Identifier }\end{array}$ & Date & $\begin{array}{c}\text { Time of } \\
\text { measurement }\end{array}$ & $\begin{array}{l}\text { Water level altitude } \\
\text { (feet above NAVD 88) }\end{array}$ \\
\hline \multirow[t]{2}{*}{$1 \mathrm{MW}-1$} & $07-12-18$ & 1029 & 6.85 \\
\hline & 08-09-18 & 1016 & 4.36 \\
\hline \multirow[t]{2}{*}{$1 \mathrm{MW}-4$} & $07-12-18$ & 1244 & 7.62 \\
\hline & 08-08-18 & 1131 & 7.10 \\
\hline \multirow[t]{2}{*}{ MW1-2 } & $07-12-18$ & 1058 & 5.43 \\
\hline & 08-09-18 & 0946 & 5.34 \\
\hline \multirow[t]{2}{*}{ MW1-9 } & $07-12-18$ & 1358 & 8.62 \\
\hline & 08-08-18 & 1501 & 7.98 \\
\hline \multirow[t]{2}{*}{ MW1-10 } & $07-12-18$ & 1413 & 8.22 \\
\hline & 08-08-18 & 1459 & 7.75 \\
\hline \multirow[t]{2}{*}{ MW1-20 } & $07-13-18$ & 0943 & 9.43 \\
\hline & 08-09-18 & 1033 & 8.96 \\
\hline \multirow[t]{2}{*}{ MW1-25 } & $07-12-18$ & 1314 & 4.71 \\
\hline & 08-08-18 & 1431 & 6.79 \\
\hline \multirow[t]{2}{*}{ MW1-29 } & $07-12-18$ & 1344 & 4.96 \\
\hline & 08-08-18 & 1446 & 6.46 \\
\hline \multirow[t]{2}{*}{ MW1-38 } & $07-11-18$ & 1214 & 2.53 \\
\hline & 08-08-18 & 1416 & 7.30 \\
\hline \multirow[t]{2}{*}{ MW1-39 } & $07-12-18$ & 0914 & 2.52 \\
\hline & 08-08-18 & 1347 & 6.39 \\
\hline \multirow[t]{2}{*}{ MW1-41 } & $07-11-18$ & 1529 & 9.94 \\
\hline & 08-08-18 & 0946 & 9.61 \\
\hline \multirow[t]{2}{*}{ MW1-43 } & $07-13-18$ & 0844 & 8.11 \\
\hline & 08-08-18 & 1547 & 7.48 \\
\hline \multirow[t]{2}{*}{ MW1-45 } & $07-13-18$ & 0858 & 6.82 \\
\hline & $08-08-18$ & 1534 & 6.53 \\
\hline \multirow[t]{2}{*}{ MW1-47 } & $07-13-18$ & 0914 & 9.16 \\
\hline & $08-08-18$ & 1531 & 8.65 \\
\hline \multirow[t]{2}{*}{ MW1-50 } & $07-12-18$ & 1144 & 5.89 \\
\hline & 08-08-18 & 1025 & 5.79 \\
\hline \multirow[t]{2}{*}{ MW1-51 } & $07-12-18$ & 1128 & 5.78 \\
\hline & 08-08-18 & 1024 & 5.56 \\
\hline \multirow[t]{2}{*}{ MW1-55 } & $07-12-18$ & 1158 & 6.70 \\
\hline & $08-08-18$ & 1031 & 6.38 \\
\hline \multirow[t]{2}{*}{ MW1-60 } & $07-13-18$ & 1029 & 7.46 \\
\hline & $08-08-18$ & 1046 & 6.06 \\
\hline \multirow[t]{2}{*}{ P1-10 } & $07-17-18$ & 1045 & 9.28 \\
\hline & 08-08-18 & 1021 & 9.05 \\
\hline
\end{tabular}


Table 4. Vertical water-quality profile measurements in selected monitoring wells at Operation Unit 1 of Naval Base Kitsap, in Keyport, Washington. July 11-August 8, 2018.

[Note: Spring tidal low-low on July 11, 2018, occurred at 1041 hours; spring tidal low-low on July 12, 2018, occurred at 1103 hours; and spring tidal low-low on August 8, 2018, occurred at 0905 hours. Abbreviations and symbol: ${ }^{\circ} \mathrm{C}$, degrees Celsius; $\mu \mathrm{S} / \mathrm{cm}$, microsiemens per centimeter at 25 degrees Celsius; -, parameters were stable, but time was not recorded]

\begin{tabular}{|c|c|c|c|c|c|c|}
\hline $\begin{array}{l}\text { Monitoring } \\
\text { well } \\
\text { identifier }\end{array}$ & Date & $\begin{array}{c}\text { Time of } \\
\text { measurement }\end{array}$ & $\begin{array}{l}\text { Depth } \\
\text { (feet) }\end{array}$ & $\begin{array}{c}\text { Temperature } \\
\left({ }^{\circ} \mathrm{C}\right)\end{array}$ & $\begin{array}{c}\text { Specific } \\
\text { conductance } \\
(\mu \mathrm{S} / \mathrm{cm})\end{array}$ & $\begin{array}{c}\text { Tidal } \\
\text { condition }\end{array}$ \\
\hline \multirow[t]{4}{*}{$1 \mathrm{MW}-1$} & $07-12-2018$ & 1402 & 7.5 & 18.0 & 170 & \multirow{3}{*}{ Ebb } \\
\hline & $07-12-2018$ & 1404 & 9 & 17.3 & 180 & \\
\hline & $07-12-2018$ & 1405 & 14 & 15.3 & 279 & \\
\hline & 08-08-2018 & 1510 & 8.5 & 18.5 & 128 & \multirow[t]{2}{*}{ Flood } \\
\hline \multirow[t]{4}{*}{$1 \mathrm{MW}-4$} & $07-12-2018$ & 1256 & 15 & 21.4 & 650 & \\
\hline & $07-12-2018$ & - & 20 & 16.8 & 923 & \multirow[t]{2}{*}{ Flood } \\
\hline & $07-12-2018$ & ${ }^{1} 1304$ & 25 & 14.9 & 1,016 & \\
\hline & 08-08-2018 & 1145 & 20 & 13.5 & 1,059 & Flood \\
\hline \multirow[t]{2}{*}{ MW1-2 } & $07-12-2018$ & 1047 & 12.5 & 18.3 & 541 & $\mathrm{Ebb}$ \\
\hline & $08-08-2018$ & 1050 & 17 & 14.2 & 709 & Ebb \\
\hline \multirow[t]{4}{*}{ MW1-9 } & $07-12-2018$ & 1341 & 48 & 16.1 & 435 & \multirow{3}{*}{ Flood } \\
\hline & $07-12-2018$ & - & 53 & 14.5 & 638 & \\
\hline & $07-12-2018$ & ${ }^{1} 1350$ & 58 & 13.6 & 1,213 & \\
\hline & 08-08-2018 & 1505 & 49 & 12.8 & 575 & Flood \\
\hline \multirow[t]{4}{*}{ MW1-10 } & $07-12-2018$ & 1402 & 7.5 & 18.0 & 170 & \multirow{3}{*}{ Flood } \\
\hline & $07-12-2018$ & - & 9 & 17.3 & 180 & \\
\hline & $07-12-2018$ & ${ }^{1} 1407$ & 14 & 15.3 & 279 & \\
\hline & $08-08-2018$ & 1510 & 8.5 & 18.5 & 128 & \multirow[t]{2}{*}{ Flood } \\
\hline \multirow[t]{4}{*}{ MW1-25 } & $07-12-2018$ & 1253 & 38 & 13.0 & 964 & \\
\hline & $07-12-2018$ & - & 44 & 13.3 & 1,013 & \multirow[t]{2}{*}{ Flood } \\
\hline & $07-12-2018$ & ${ }^{1} 1302$ & 48 & 12.8 & 1,027 & \\
\hline & 08-08-2018 & 1435 & 43 & 13.6 & 911 & Flood \\
\hline \multirow[t]{4}{*}{ MW1-29 } & $07-12-2018$ & 1321 & 32 & 13.0 & 2,198 & \multirow{3}{*}{ Flood } \\
\hline & $07-12-2018$ & - & 35 & 12.5 & 2,226 & \\
\hline & $07-12-2018$ & ${ }^{1} 1326$ & 37 & 12.4 & 2,610 & \\
\hline & $08-08-2018$ & 1450 & 35 & 12.7 & 2,258 & Flood \\
\hline \multirow[t]{5}{*}{ MW1-38 } & $07-11-2018$ & 1445 & 44 & 13.4 & 943 & \multirow{3}{*}{ Flood } \\
\hline & $07-11-2018$ & - & 47.5 & 13.7 & 901 & \\
\hline & $07-11-2018$ & ${ }^{1} 1451$ & 49 & 14.1 & 1,117 & \\
\hline & 08-08-2018 & 1405 & 44 & 14.3 & 1,405 & \multirow[b]{2}{*}{ Flood } \\
\hline & 08-08-2018 & 1410 & 49 & 13.2 & 1,410 & \\
\hline \multirow[t]{2}{*}{ MW1-39 } & $07-12-2018$ & 0902 & 30 & - & - & Ebb \\
\hline & $08-08-2018$ & 1355 & 30 & 13.9 & 433 & Flood \\
\hline
\end{tabular}

${ }^{1}$ Time of measurement (HH:MM) is estimated; profiling duration was 3-10 minutes based on profile length and time for sensor to equilibrate at each depth. 


\section{Surface-Water Sensor Deployment and Survey}

Each surface-water monitoring site deployment required unique positioning and deployment techniques. Different types of sensor anchor systems were used with consideration of bottom substrate and the need to withstand constant streamflow or repeated semidiurnal tidal flow. The Shallow Lagoon and Liberty Bay sites are tidal flow sites with extremely soft substrate requiring a large footprint anchor; CTDs at those sites were secured to cinderblock anchors to provide weight and stability. The Liberty Bay CTD was deployed underwater at the Keyport, Washington, public marina dock adjacent to a dock pier at about the time of the daily lower-low tide to ensure that the transducer would remain submerged for the duration of deployment. The water-column height above the CTD was $3.05 \mathrm{ft}$ during sensor deployment at 1000 hours on July 11, 2018. The Shallow Lagoon CTD was deployed on July 11, 2018, about $30 \mathrm{ft}$ offshore with a water column height above the transducer of $2.78 \mathrm{ft}$ at 1445 hours. At the Marsh Creek, Tide Flats, and Marsh Pond sites, CTDs were secured to fence-post or steel-rod anchors pounded vertically into the substrate. CTDs were mounted on the anchor about $0.20 \mathrm{ft}$ above the substrate to ensure that the transducers would remain submerged.

Once CTDs were mounted and secured in place, the distance between the anchor Measuring Point (MP) and the overlying water surface (tape-down value) was measured. During a return field visit on August 8, 2018, the altitudes of surface-water monitoring site MPs were surveyed relative to the known NAVD 88 MP altitudes of nearby monitoring wells or Washington Department of Transportation survey monument identification number 3180, located on the causeway along State Route 308 near wells MW1-38 and 39. The tape-down value was then used to determine the sensor offset for converting surface-water-level data to surface-water altitudes referenced to NAVD 88 (table 5). 
Table 5. Water levels measured during deployment and retrieval of conductance-temperature-depth sensors at surface-water sites bounding Operation Unit 1 of Naval Base Kitsap, in Keyport, Washington, July 11-August 9, 2018.

[Time of Measurement: This time references the nearest time-series water-height data value for an offset calculation. Abbreviation: NAVD 88, North American Vertical Datum 1988]

\begin{tabular}{lccc}
\hline $\begin{array}{c}\text { Surface-water site } \\
\text { identifier }\end{array}$ & Date & $\begin{array}{c}\text { Time of } \\
\text { measurement }\end{array}$ & $\begin{array}{c}\text { Surface water altitude } \\
\text { (feet above NAVD 88) }\end{array}$ \\
\hline Shallow Lagoon & $07-11-2018$ & 1445 & 8.92 \\
& $08-08-2018$ & 0930 & 9.02 \\
Marsh Pond & $07-11-2018$ & 1400 & 5.75 \\
& $08-08-2018$ & 1100 & 5.32 \\
Marsh Creek & $07-11-2018$ & 1315 & 5.00 \\
& $08-08-2018$ & 1215 & 5.02 \\
Tide Flats & $07-12-2018$ & 0945 & 2.12 \\
& $08-08-2018$ & 1200 & 1.94 \\
Liberty Bay & $07-11-2018$ & 1000 & -5.31 \\
& $08-09-2018$ & 0900 & -3.76 \\
\hline
\end{tabular}

\section{Sensor Retrieval}

During August 8-9, 2018, a USGS field team retrieved the 9 CTDs and 10 PTs from monitoring wells. All wells were accessed, and depth-to-water measurements were recorded prior to the final 15-minute measurement (table 3). Initial data review indicated that CTDs deployed in the nine groundwater monitoring wells successfully recorded water levels and temperatures but failed to record specific conductance or salinity over the entire deployment. The field team also retrieved the five CTDs from the surface-water site where conductance, temperature, and depth were all successfully recorded. A final tape-down from each surveyed MP was measured on the 15-minute sample interval prior to removing the surface-water monitoring site anchors and instruments (table 5).

\section{Time-Series Data Processing}

The 15-minute time series data from the CTDs were downloaded in the field. Groundwater, surface-water, and seawater time-series water-level data measured with nonvented pressure transducers were adjusted for changes in atmospheric pressure by subtracting the atmospheric (barometric) pressure, measured with a barometric pressure logger at the site, from the pressure transducer measurements for each 15-minute value, with due consideration of units. The 15-minute time-series data from the PTs also were downloaded in the field. Data measured with these vented pressure transducers required no barometric pressure correction. 


\section{Results and Discussion}

\section{Vertical Water-Quality Profiles}

The vertical water-quality profile data often showed a gradual increase in specific conductance with depth across the saturated screened intervals of the nine profiled wells (table 4). The profiles were measured immediately preceding the lower-low tide of $-6.34 \mathrm{ft}$ at 1103 hours on July 12, 2018, or during the following flood as high as $9.12 \mathrm{ft}$ at 1824 hours. All measurements indicated water was fresh (specific conductance less than $1,000 \mu \mathrm{S} / \mathrm{cm}$ ) or slightly brackish (specific conductance of 1,000-10,000 $\mu \mathrm{S} / \mathrm{cm}$ ), with no actual seawater (specific conductance greater than $10,000 \mu \mathrm{S} / \mathrm{cm}$ ) or sharp freshwater/seawater interface found. For comparison, specific conductance values measured during 1999-2014 in OU 1 wells at midscreen depths ranged from about 200 to 3,400 $\mu \mathrm{S} / \mathrm{cm}$ (Huffman, 2015), while specific conductance values measured in 2017 at Keyport Area 8 wells that were influenced by tides and subject to seawater intrusion were as much as $44,000 \mu \mathrm{S} / \mathrm{cm}$ (Opatz and Dinicola, 2018). The vertical gradients measured in 2018 were similar to those measured in the same wells during a salinity study done during July 1996 (URS Consultants, Inc., 1997), as was the range of measured specific conductance (200-3,100 $\mu \mathrm{S} / \mathrm{cm}$ measured in the same nine wells in 1996.)

With regard to optimal sampling depths, groundwater chemistry samples collected from the middle of the well screens at OU 1 wells can be assumed to be reasonably representative of undiluted groundwater at that location. Sampling from the top of the water table would further reduce the possibility for dilution by transient seawater intrusion, but it may also result in a sample that is less representative of contaminated groundwater flowing from the landfill at depths of 10-40 ft where high concentrations of chlorinated VOCs beneath the landfill have been measured (Department of the Navy, 2018).

\section{Time-Series Groundwater and Tidal Level Data}

Time-series of measured groundwater levels, and tidal levels at Liberty Bay and Tide Flats are shown in figures 3-15 (at back of report) for the 18 OU 1 wells monitored. All water levels are referenced to feet above NAVD 88.

Groundwater levels in the tidally influenced wells fluctuated semidiurnally in concert with but attenuated in time and magnitude with the semidiurnal tides. The lowest groundwater levels measured in all shallow wells were associated with the spring tides around July 13, when the low-low tidal levels were lowest.

\section{Tidal Lag in Monitoring Wells}

The time series of groundwater levels from each well and the corresponding tidal level data from Liberty Bay (figs. 3-14, at back of report) were used to calculate tidal lag times for 12 of the 18 monitored wells (table 6). Groundwater levels in the remaining six measured wells were minimally influenced (by less than $0.01 \mathrm{ft}$ ) by tides (fig. 15, at back of report), indicating that sampling schedules for those wells should not be constrained by tidal conditions. The tidal lags were determined relative to tidal levels in Liberty Bay (rather than in the Tide Flats) because the NOAA-predicted tides that will be used to schedule groundwater sampling represent openwater conditions in the area, and the sill that separates Dogfish Bay from the Tide Flats clearly affects the timing and magnitude of low-low tides in the Tide Flats. 
Each semidiurnal low-low tidal level in Liberty Bay was followed by a low-low groundwater level in the 12 monitoring wells influenced by tides. The time difference between the tidal and groundwater low-lows (tidal lag) was calculated for each day and each well, and the range of the tidal lags was noted (table 6). Over the duration of the data collection period that included spring and neap tides, tidal lags ranged from 0 to 5.0 hours for all wells, with the longest tidal lags (3.75-5.0 hours) in well MW1-45.

Table 6. Ranges of time differences (tidal lags) between a minimum groundwater level altitude in a monitoring well and the preceding low-low tide calculated from data collected at Operable Unit 1 of Naval Base Kitsap, in Keyport, Washington. July 12-August 8, 2018.

\begin{tabular}{lc}
\hline $\begin{array}{c}\text { Monitoring } \\
\text { well } \\
\text { identifier }\end{array}$ & $\begin{array}{c}\text { Range of tidal lags between recorded } \\
\text { minimum tide and minimum } \\
\text { groundwater levels (hours) }\end{array}$ \\
\hline MW1-9 & 0 \\
MW1-38 & 0 \\
MW1-39 & 0 \\
MW1-60 & $2.0-4.0$ \\
MW1-2 & $3.5-4.0$ \\
MW1-29 & $3.25-4.25$ \\
MW1-25 & $3.5-3.75$ \\
1MW-1 & $3.5-4.25$ \\
MW1-43 & $3.5-4.25$ \\
MW1-47 & $3.75-4.25$ \\
MW1-45 & $3.75-5.0$ \\
1MW-4 & 4.25 \\
MW1-10 & Minimal tidal response \\
MW1-41 & Minimal tidal response \\
MW1-50 & Minimal tidal response \\
MW1-51 & Minimal tidal response \\
MW1-20 & Minimal tidal response \\
P1-10 & Minimal tidal response \\
\hline
\end{tabular}

Lag times were divided into three general groups: (1) wells where groundwater responded to tidal levels immediately (fig. 16), (2) wells where groundwater responded to tidal levels within about 2-5 hours (fig. 17), and (3) wells where groundwater had minimal response to tidal levels (fig 18) (figs. 16-18, at back of report).

Wells where groundwater responded to tidal levels immediately (wells MW1-9, MW138, and MW1-39) were relatively deep and located adjacent to a shoreline, although two other deep shoreline wells (wells MW1-29 and MW1-25) had approximately 2-4-hour tidal lags. The magnitude of the groundwater response to tides in MW1-9 (fig. 5) was marginally greater than the 0.01-ft threshold. With one exception (MW1-10), wells where groundwater did not respond to tidal levels were those farthest away from Tide Flats and Liberty Bay. The wells where groundwater responded within about 2-5 hours to tidal levels all seemed to respond in concert with tidal levels in the Tide Flats rather than tidal levels in Liberty Bay. Seawater flow in and out of the Tide Flats is restricted by the State Route 308 berms and a sill beneath the bridge with a top altitude of about $0 \mathrm{ft}$. This sill effectively limits the low-altitude water levels in the Tide Flats to about $0 \mathrm{ft}$ because the exposed Tide Flats sediments remain saturated at that level, whereas tidal levels in Liberty Bay continue to ebb. By essentially maintaining a water level of about $0 \mathrm{ft}$ in the Tide Flat during low tides, the sill also delays the groundwater response to rising tides in 
Liberty Bay until the tide level exceeds the 0 -ft sill altitude and saltwater again floods the Tide Flats. The dominant groundwater response to Tide Flats tidal levels is most clearly indicated in wells MW1-29 (fig. 6) and MW1-25 (fig. 7). A similar response was measured in wells MW160, MW1-2, 1MW-1, MW1-43, MW1-47, MW1-45, and 1MW-4. For the group of wells that respond most closely to Tide Flats tidal levels, tidal lag times were substantially shorter during neap tides where the low-low tide in Liberty Bay remained above or close to the 0 -ft sill altitude (for example, July 18-19 in fig. 7).

\section{Surface-Water Levels and Specific Conductance in Water Bodies Surrounding}

\section{Operable Unit 1}

Time-series of surface-water and tidal levels were measured (referenced to NAVD 88) in Marsh Pond, Shallow Lagoon, and Marsh Creek, in addition to Tide Flats and Liberty Bay (fig. 19, at back of report). These data were collected primarily to support a parallel groundwater modeling effort at OU 1, although they also provide insight into groundwater response to changes in surface water levels in the different water bodies.

All surface-water levels fluctuated semidiurnally in concert with, but attenuated in magnitude with, the semidiurnal tides. Marsh Pond and Marsh Creek are separated from the Tide Flats by a tide gate that by design restricts seawater inflow into the marsh system to maximum levels of about $+6.4 \mathrm{ft}$. Minimum surface-water levels in the marsh are limited to the marsh ground altitude of approximately $+5 \mathrm{ft}$. Water levels in the Shallow Lagoon are primarily controlled by a sill at the lagoon outlet at approximately $+8.75 \mathrm{ft}$, and perennial inflow of freshwater into the lagoon from adjacent creeks. There is no inflow to the Shallow Lagoon from Port Orchard Bay (directly connected to Liberty Bay) during the neap tides (such as during July $21-25,2018)$ when the high-high tides remained below the sill altitude. During the neap tides monitored for this study, freshwater surface inflows where not large enough to maintain a constant water level in the Shallow Lagoon so the water-surface altitude declined 0.27 feet until July 26, when higher tides again exceeded the sill altitude. The greatly attenuated water-level fluctuations in the Shallow Lagoon do not appear to influence groundwater levels in OU 1 wells on a transient scale, as evidenced by the lack of groundwater response to tides in wells MW1-20, P1-10, MW1-50 and MW1-51 (fig. 15). Water levels in the Shallow Lagoon do influence the steady-state position of that groundwater divide. If the lagoon experienced the full tidal range, the mean water level in the lagoon would be lower than it experiences now, and the groundwater divide would be closer to OU1.

Specific conductance also was measured every 15 minutes in these surface-water bodies (fig. 20, at back of report). The water was consistently saline in all water bodies, with specific conductance ranging from about 38,000 to $45,000 \mu \mathrm{S} / \mathrm{cm}$, and with Shallow Lagoon and Marsh Pond being less saline than the other water bodies.

\section{Optimal Depths and Time for Groundwater Sampling}

With regard to optimal sampling depths, groundwater chemistry samples collected from the middle of the well screens at OU 1 wells can remain the standard practice at each location given that no tidal-induced changes in the subtle freshwater/seawater interface have yet been identified in the screened interval of the wells. Collection of specific conductance time-series data from the wells, as was intended for this study, would better support that practice. 
When sampling during spring (rather than neap) tides as has generally been the standard practice at OU 1, by insuring the greatest groundwater gradient seaward produced by the lower low-low tide level, the optimal time to sample the monitoring wells influenced by tides would be to add the tidal lags in table 6 to the time of the predicted low-low tide for Poulsbo, Washington (NOAA Station 9445719.) Sampling schedules for the six wells where groundwater levels were only minimally influenced by tides need not be constrained by tidal conditions. 


\section{References Cited}

Department of the Navy, 2018, Draft 2017 site recharacterization, Phase II, Operable Unit 1, Naval Base Kitsap, Keyport, Washington: Prepared for Department of the Navy, Naval Facilities Engineering Command Northwest by Battelle Memorial Institute, Contract No. N39430-16-D-1802, Delivery Order 0010.

Huffman, R.L., 2015, Groundwater geochemical and selected volatile organic compound data, Operable Unit 1, Naval Undersea Warfare Center, Division Keyport, Washington, June and September 2014: U.S. Geological Survey Data Series 920, 50 p., http://dx.doi.org/10.3133/ds920.

Opatz, C.C., 2019, Groundwater, surface water, and tidal time series data, OU1 Naval Base Kitsap Keyport, WA: U.S. Geological Survey data release, https://doi.org/10.5066/P9FB3KLK.

Opatz, C.C., and Dinicola, R.S., 2018, Analysis of groundwater response to tidal fluctuations, Operable Unit 2, Area 8, Naval Base Kitsap, Keyport, Washington: U.S. Geological Survey Open-File Report 2018-1082, 20 p., https://doi.org/10.3133/ofr20181082.

Rasmussen, T.C., and Crawford, L.A., 1997, Identifying and removing barometric pressure effects in confined and unconfined aquifers: Groundwater, v. 35, no. 3, p. 502-511, https://doi.org/10.1111/j.1745-6584.1997.tb00111.x.

URS Consultants, Inc., 1997, Final summary data assessment report for Operable Unit 1 Naval Undersea Warfare Center Division Keyport, Washington: Prepared by URS Consultants, Seattle, Washington, for Engineering Field Activity, Northwest, Naval Facilities Engineering Command, Poulsbo, Washington, 3 vols. 


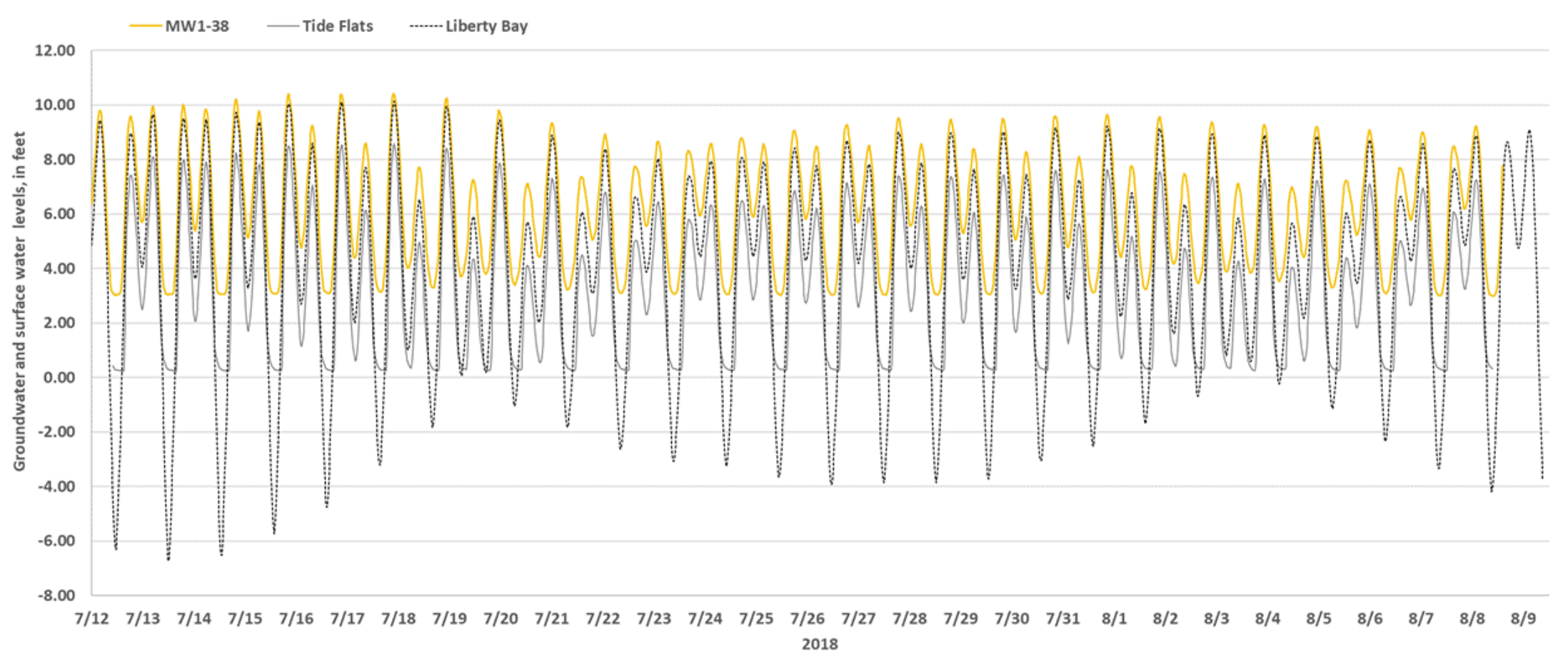

Figure 3. Graph showing groundwater levels in monitoring well MW1-38 and tidal levels of Tide Flats and Liberty Bay at Operation Unit 1 of Naval Base Kitsap, in Keyport, Washington, July 12-August 9, 2018. All levels are in feet above North American Vertical Datum of 1988. 


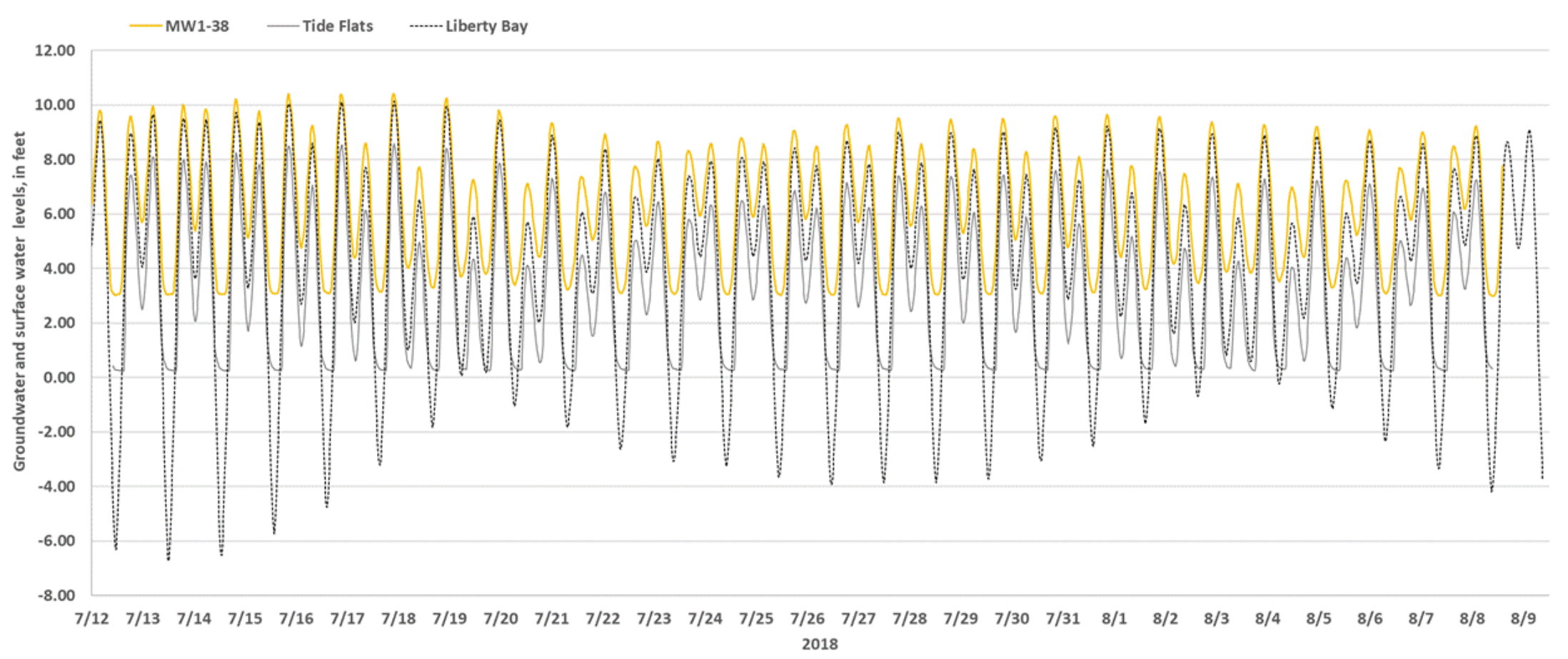

Figure 4. Graph showing groundwater levels in monitoring well MW1-39 and tidal levels of Tide Flats and Liberty Bay at Operable Unit 1 of Naval Base Kitsap, in Keyport, Washington, July 12-August 9, 2018. All levels are in feet above North American Vertical Datum of 1988. 


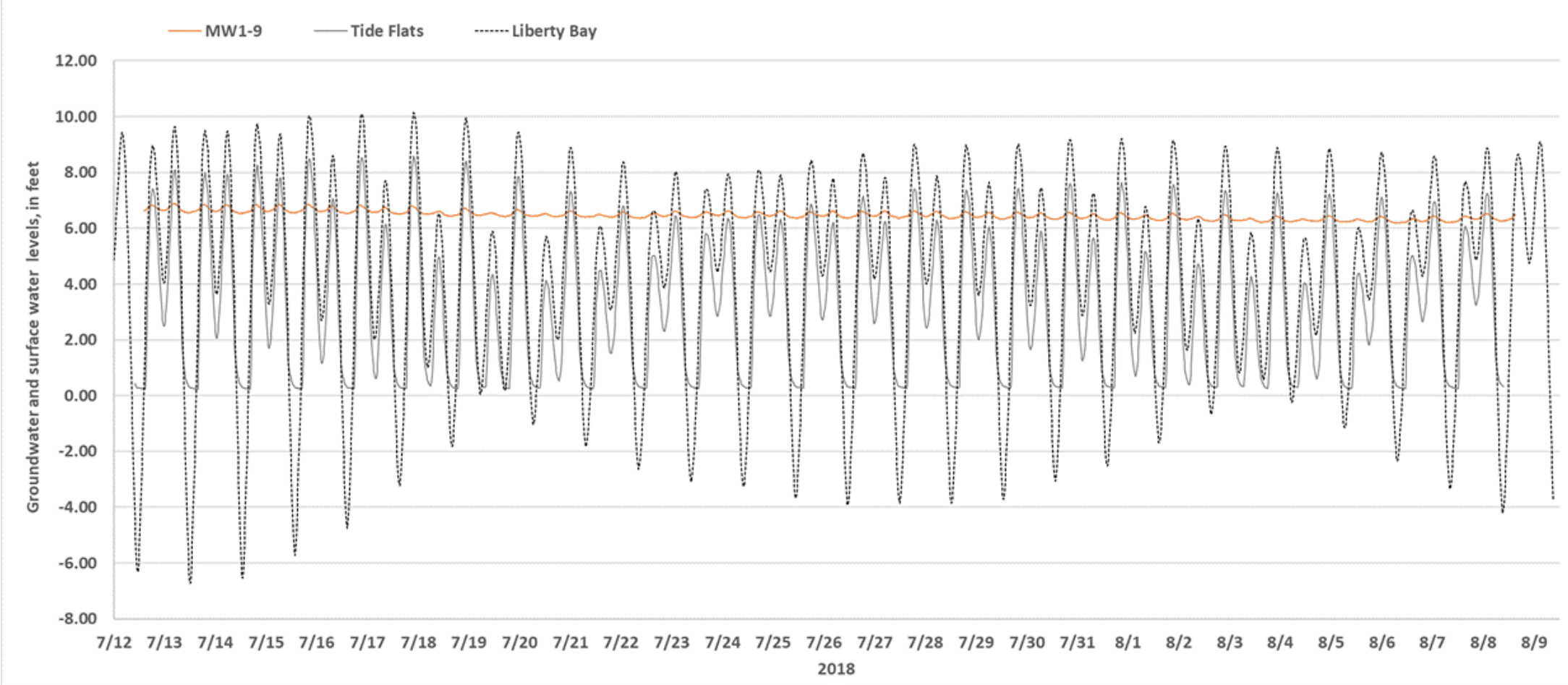

Figure 5. Graph showing groundwater levels in monitoring well MW1-9 and tidal levels of Tide Flats and Liberty Bay at Operable Unit 1 of Naval Base Kitsap, in Keyport, Washington, July 12-August 9, 2018. All levels are in feet above North American Vertical Datum of 1988. 


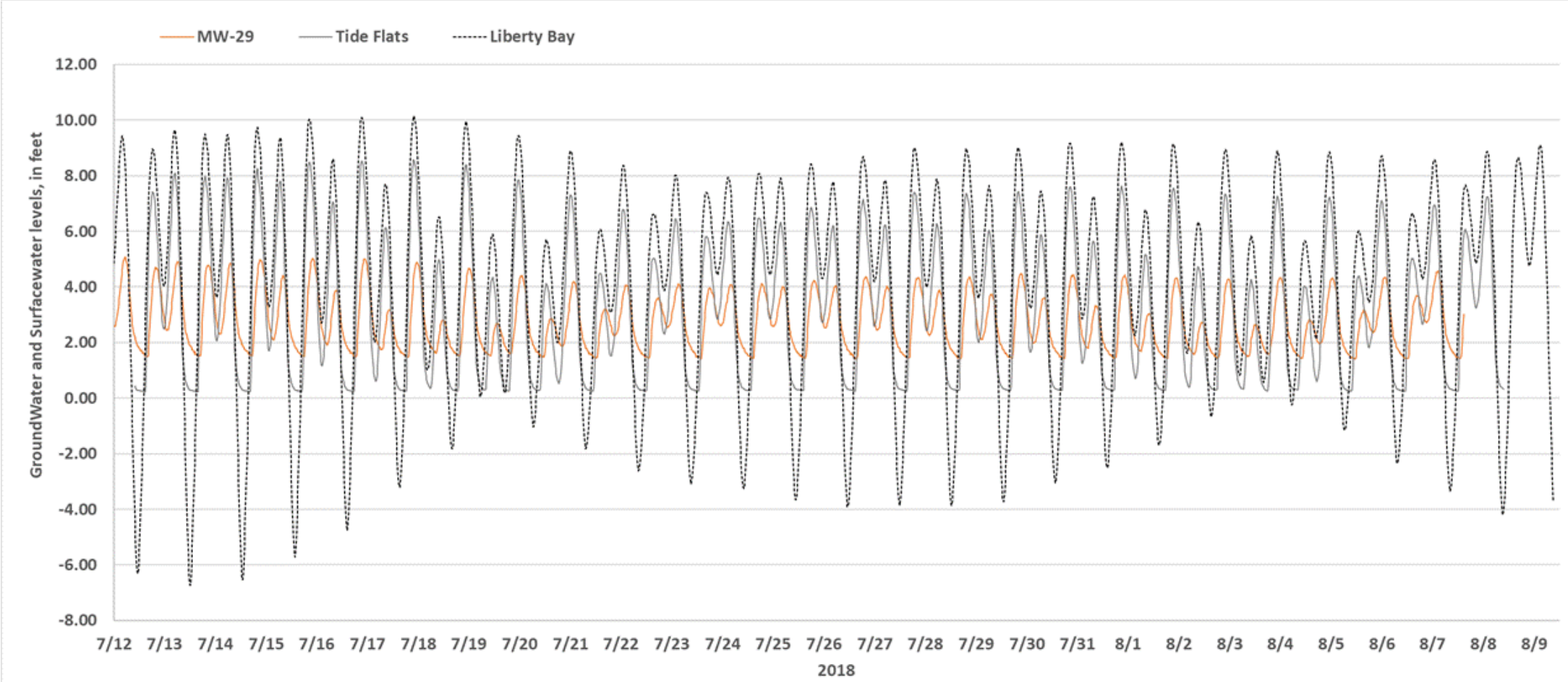

Figure 6. Graph showing groundwater levels in monitoring well MW1-29 and tidal levels of Tide Flats and Liberty Bay at Operable Unit 1 of Naval Base Kitsap, in Keyport, Washington, July 12-August 9, 2018. All levels are in feet above North American Vertical Datum of 1988. 


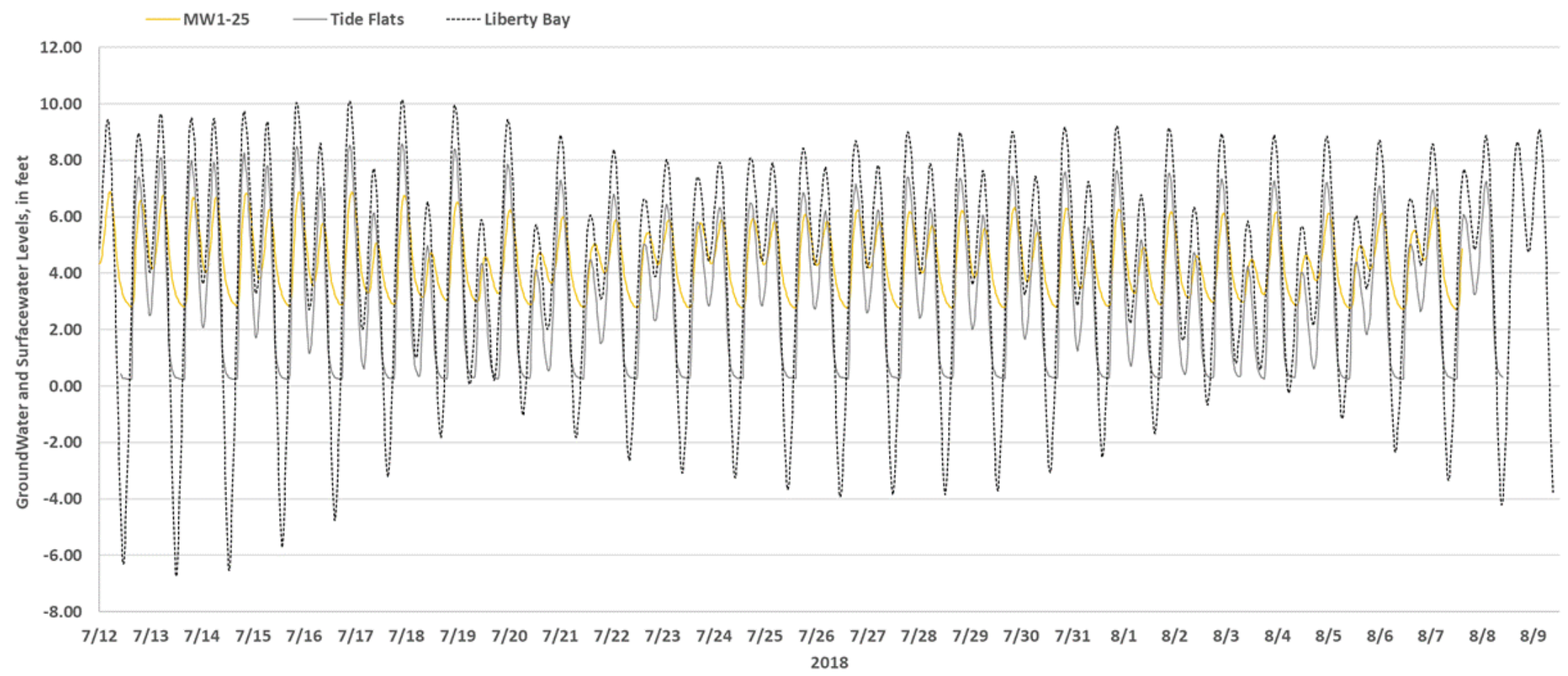

Figure 7. Graph showing groundwater levels in monitoring well MW1-25 and tidal levels of Tide Flats and Liberty Bay at Operable Unit 1 of Naval Base Kitsap, in Keyport, Washington, July 12-August 9, 2018. All levels are in feet above North American Vertical Datum of 1988. 


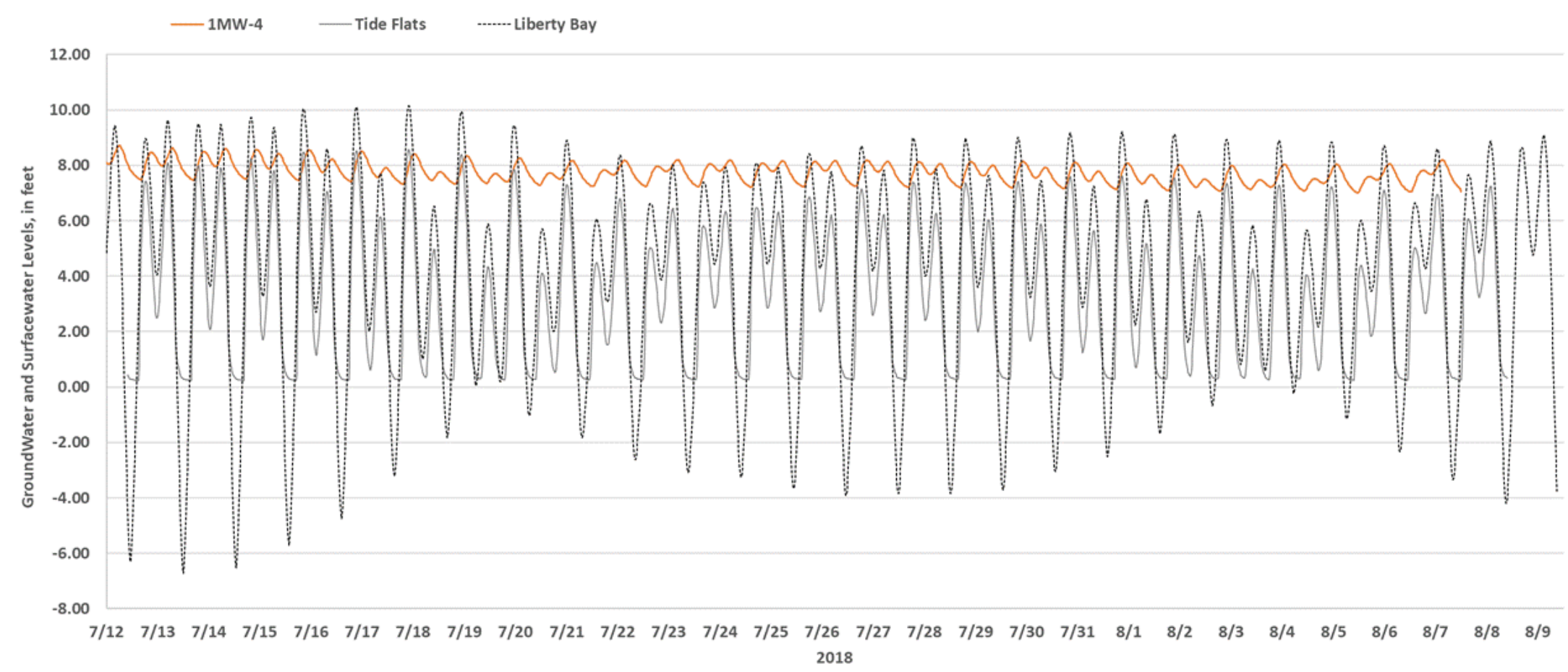

Figure 8. Graph showing groundwater levels in monitoring well $1 \mathrm{MW}-4$ and tidal levels of Tide Flats and Liberty Bay at Operable Unit 1 of Naval Base Kitsap, in Keyport, Washington, July 12-August 9, 2018. All levels are in feet above North American Vertical Datum of 1988. 


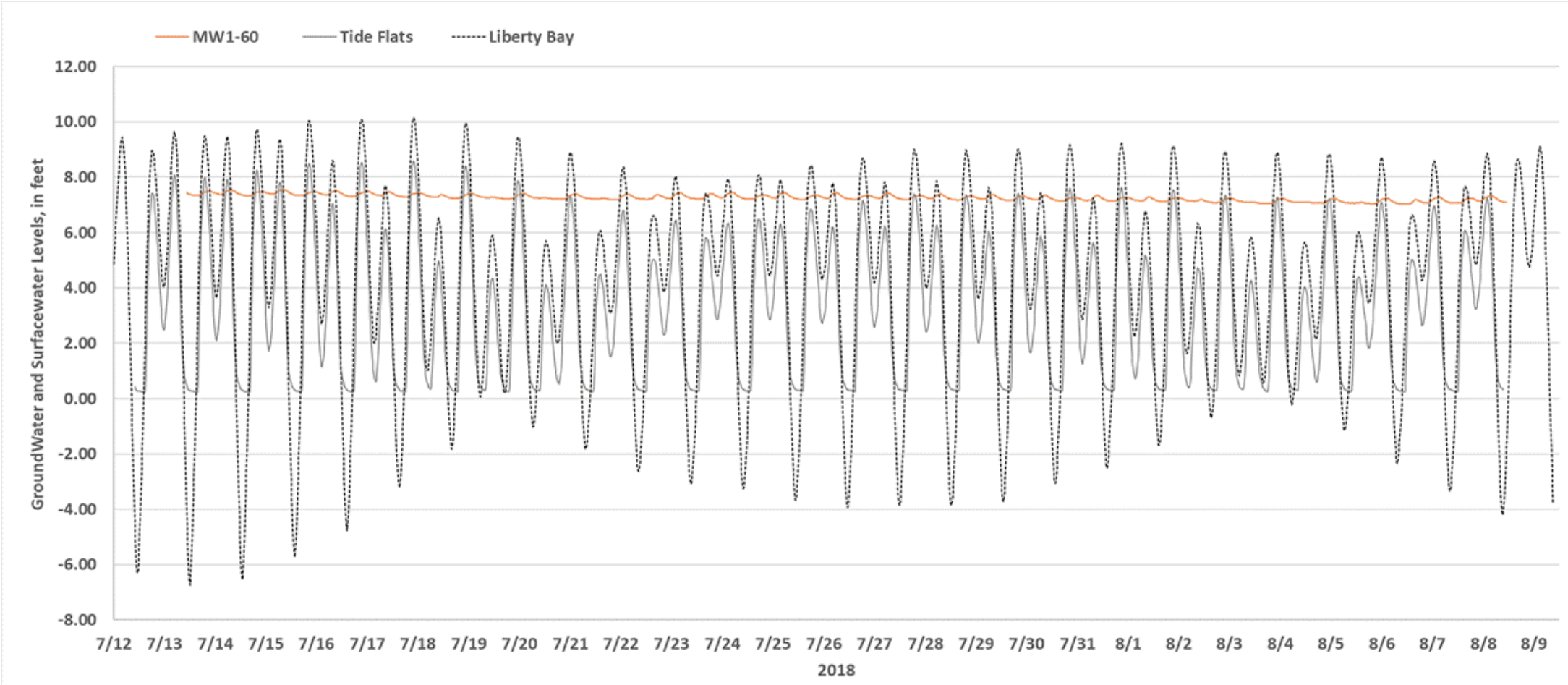

Figure 9. Graph showing groundwater levels in monitoring well MW1-60 and tidal levels of Tide Flats and Liberty Bay at Operable Unit 1 of Naval Base Kitsap, in Keyport, Washington, July 12-August 9, 2018. All levels are in feet above North American Vertical Datum of 1988. 


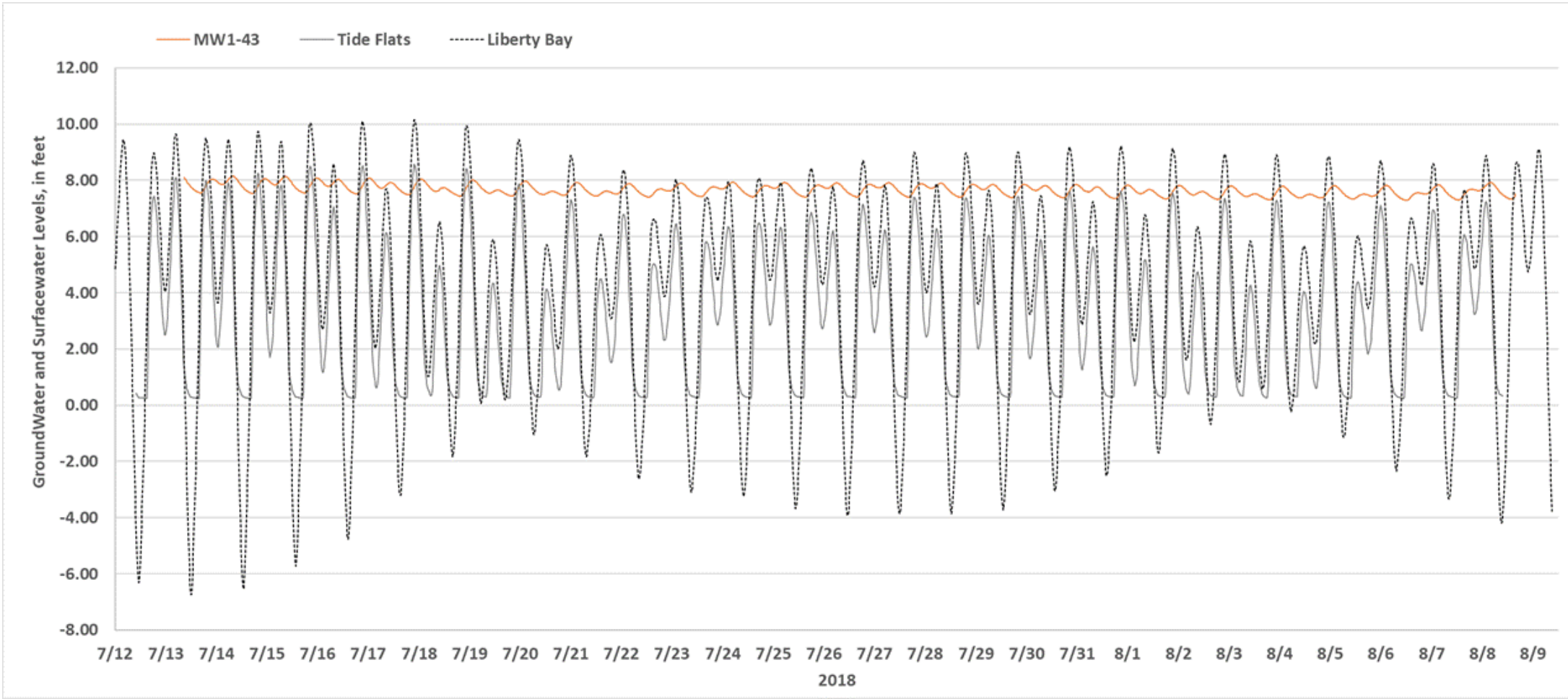

Figure 10. Graph showing groundwater levels in monitoring well MW1-43 and tidal levels of Tide Flats and Liberty Bay at Operable Unit 1 of Naval Base Kitsap, in Keyport, Washington, July 12-August 9, 2018. All levels are in feet above North American Vertical Datum of 1988. 


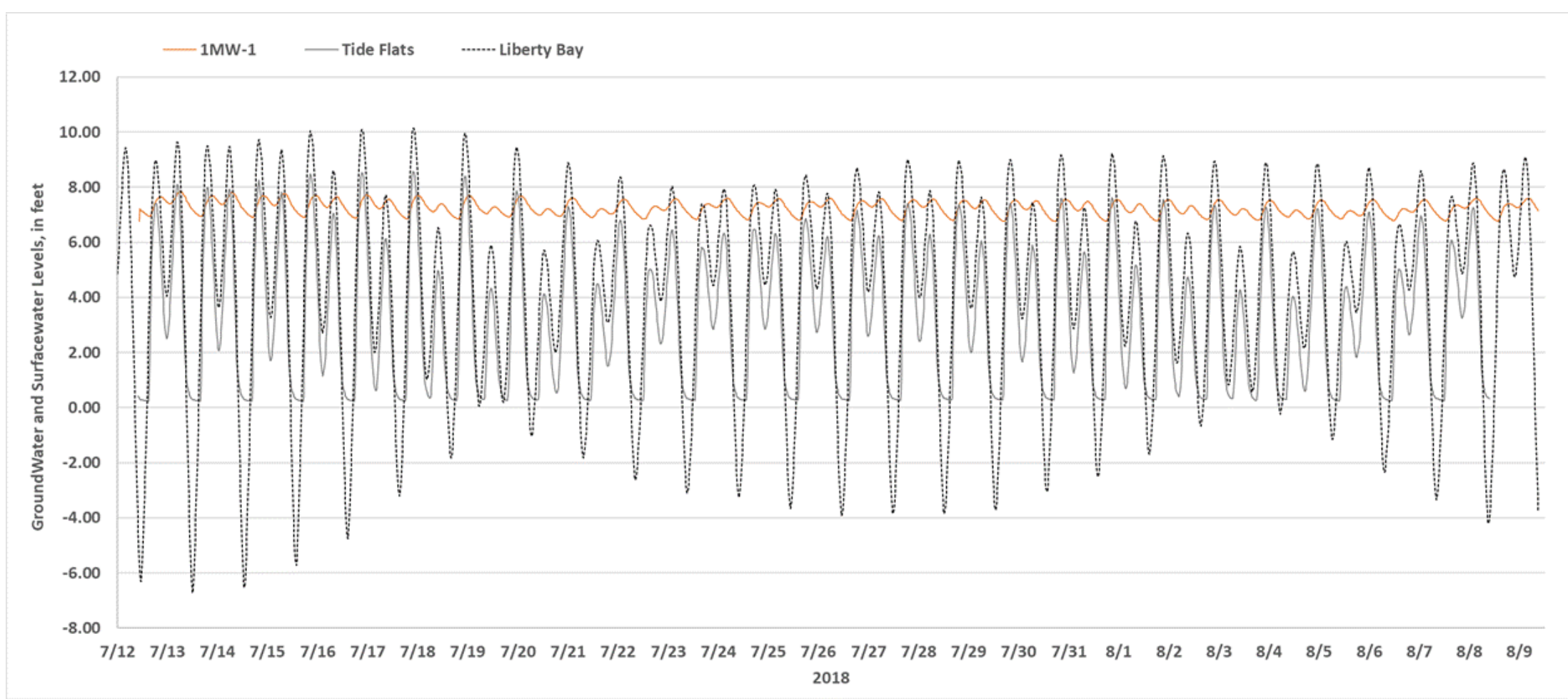

Figure 11. Graph showing groundwater levels in monitoring well $1 \mathrm{MW}-1$ and tidal levels of Tide Flats and Liberty Bay at Operable Unit 1 of Naval Base Kitsap, in Keyport, Washington, July 12-August 9, 2018. All levels are in feet above North American Vertical Datum of 1988. 


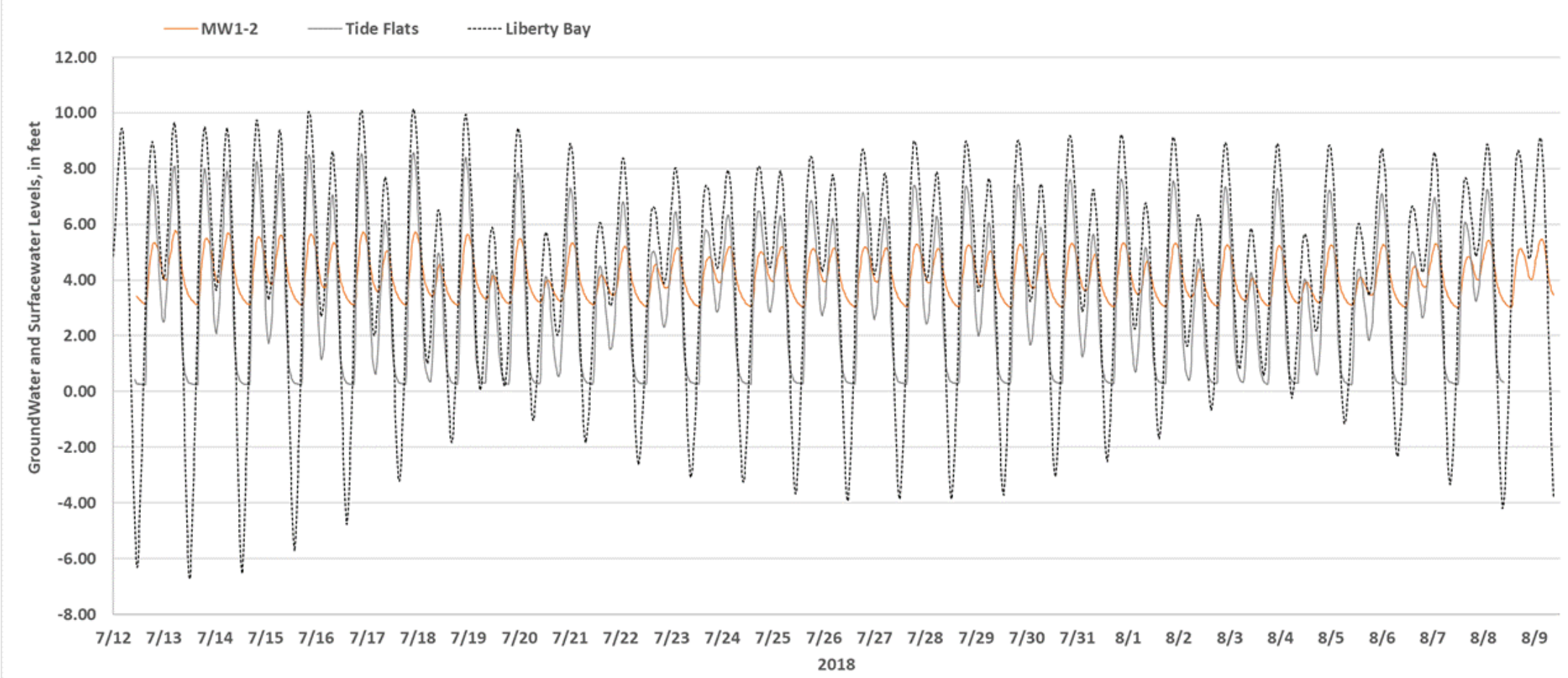

Figure 12. Graph showing groundwater levels in monitoring well MW1-2 and tidal levels of Tide Flats and Liberty Bay at Operable Unit 1 of Naval Base Kitsap, in Keyport, Washington, July 12-August 9, 2018. All levels are in feet above North American Vertical Datum of 1988. 


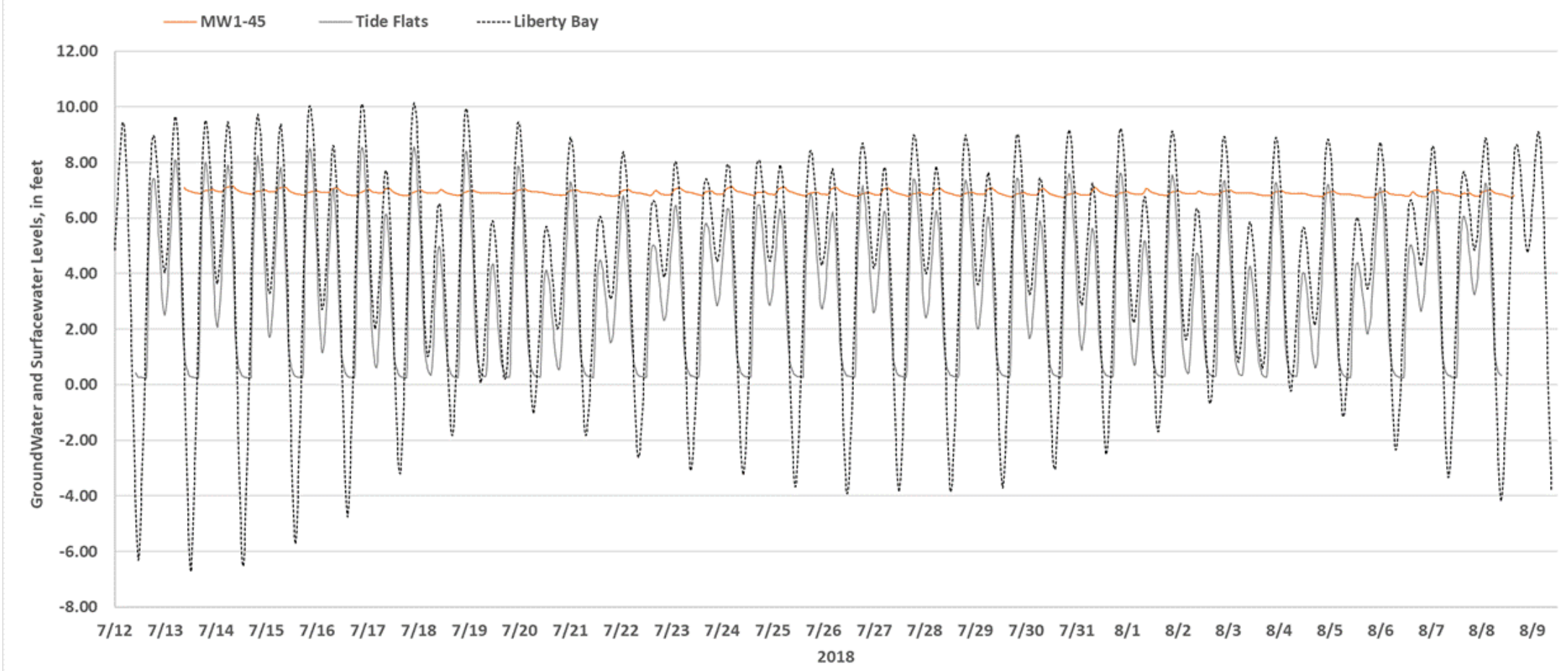

Figure 13. Graph showing groundwater levels in monitoring well MW1-45 and tidal levels of Tide Flats and Liberty Bay at Operable Unit 1 of Naval Base Kitsap, in Keyport, Washington, July 12-August 9, 2018. All levels are in feet above North American Vertical Datum of 1988. 


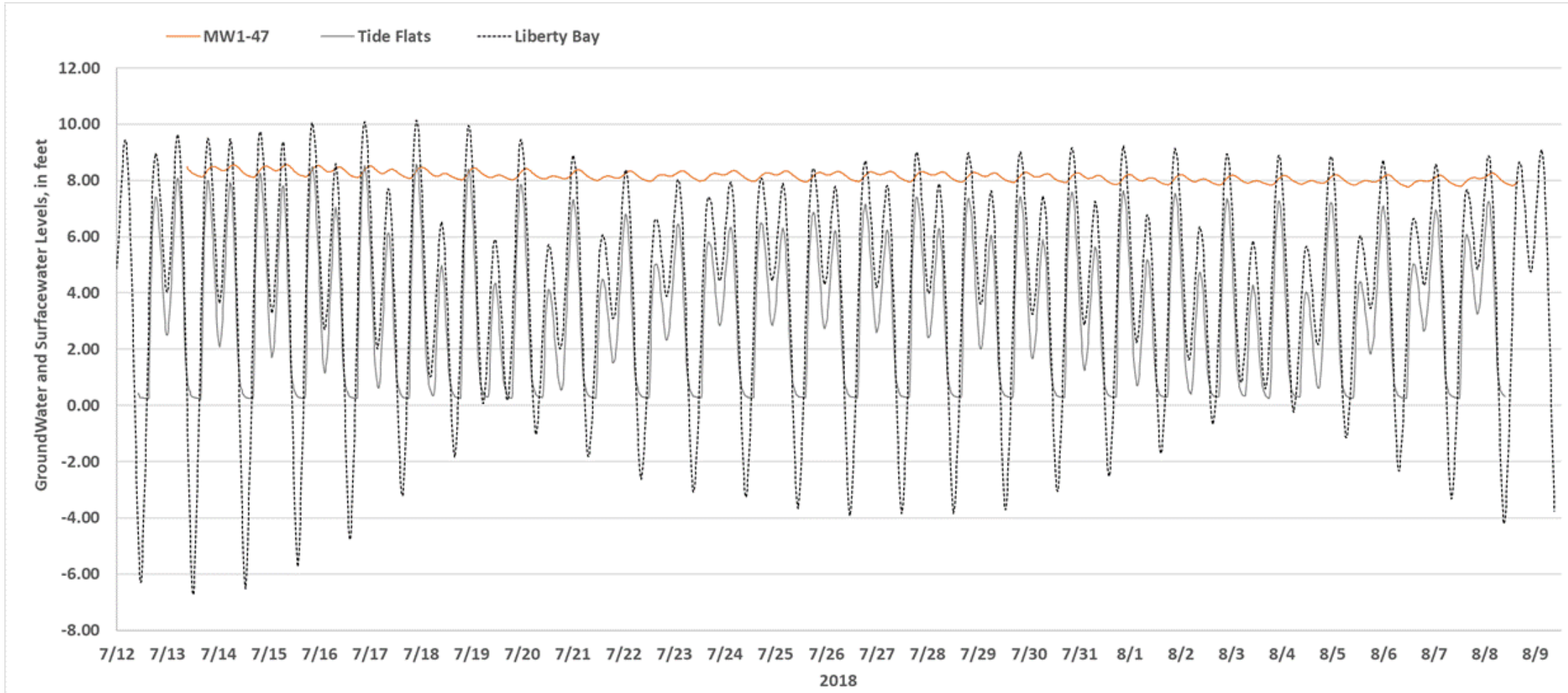

Figure 14. Graph showing groundwater levels in monitoring well MW1-47 and tidal levels of Tide Flats and Liberty Bay at Operable Unit 1 of Naval Base Kitsap, in Keyport, Washington, July 12-August 9, 2018. All levels are in feet above North American Vertical Data of 1988. 


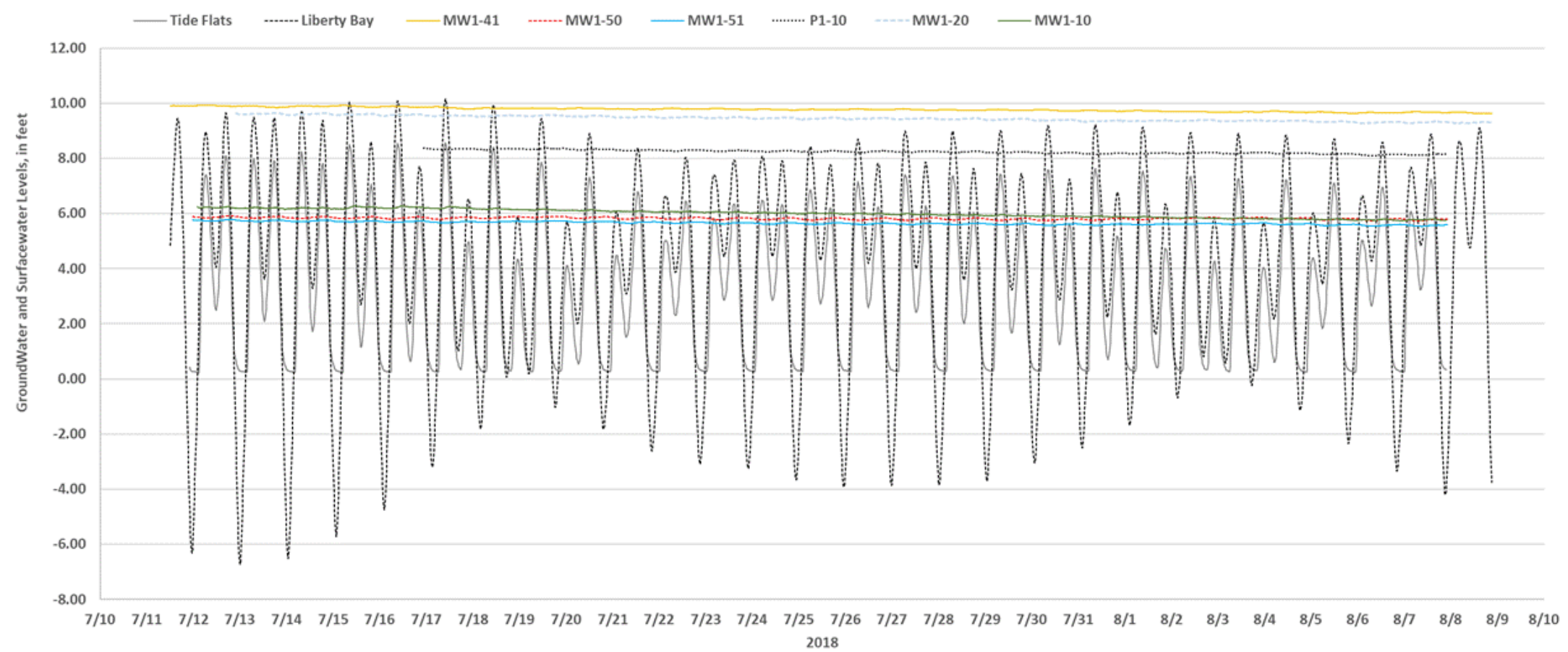

Figure 15. Graph showing groundwater levels in monitoring wells MW1-41, MW1-50, MW1-51, P1-10, MW1-20, and MW1-10, and tidal levels of Tide Flats and Liberty Bay at Operable Unit 1 of Naval Base Kitsap, in Keyport, Washington, July 12-August 9, 2018. All levels are feet above North American Vertical Data of 1988. 


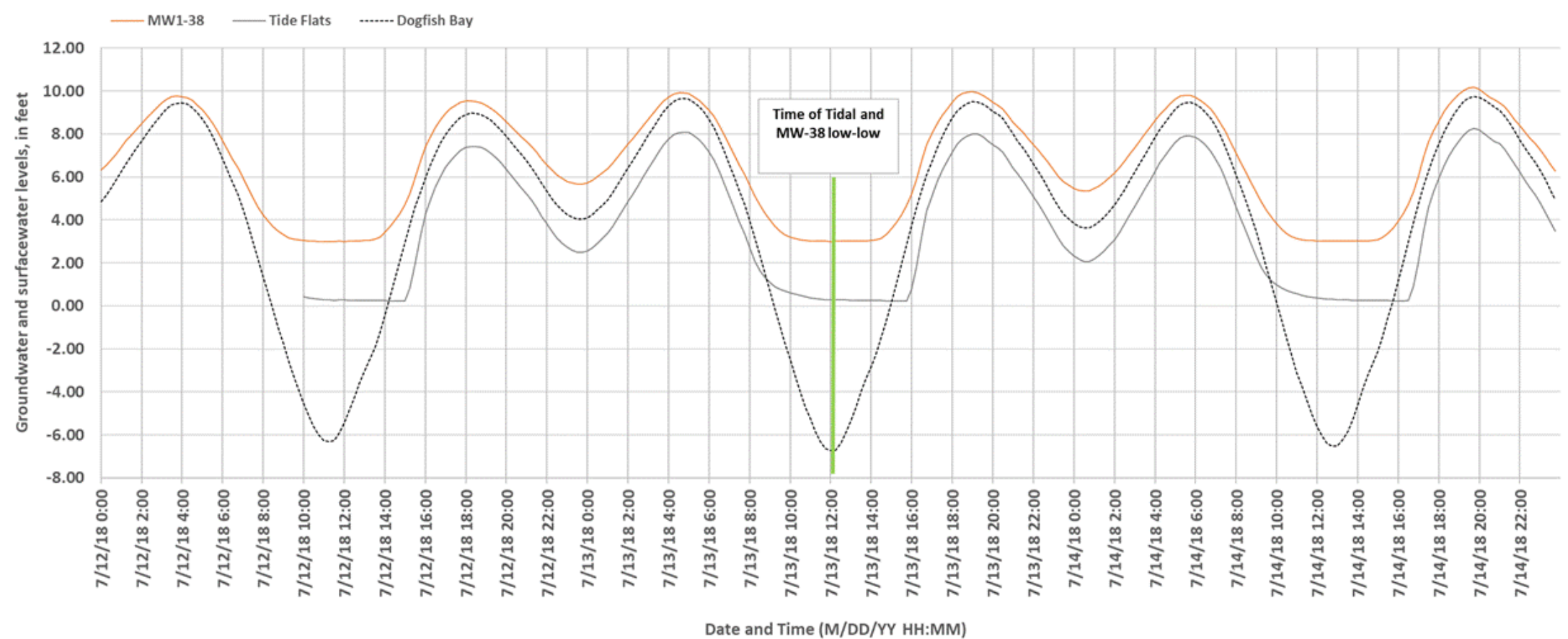

Figure 16. Representative graph showing immediate tidal response well group using monitoring well MW1-38 as an example at Operable Unit 1 of Naval Base Kitsap, in Keyport, Washington, July 12-August 14, 2018. Monitoring wells MW-39, MW-38 and MW1-9 responded immediately by the low-low in well and Liberty Bay was reached at the same time. All levels are in feet above North American Vertical Datum of 1988. 


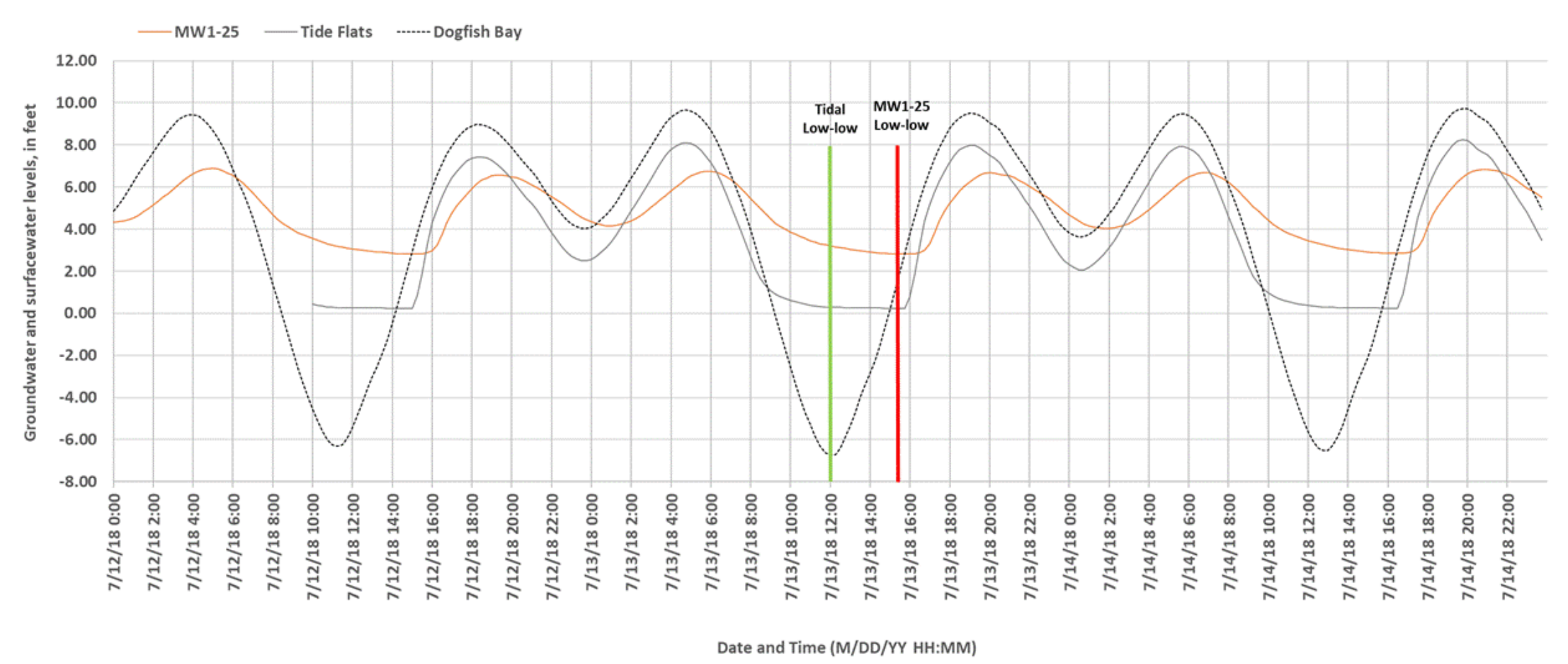

Figure 17. Representative graph showing 2-5 hour tidal response well group using monitoring well MW1-25 for an example at Operable Unit 1 of Naval Base Kitsap, in Keyport, Washington, July 12-August 14, 2018. Low-Low in monitoring wells MW1-25, MW1-60, MW1-2, MW1-29, 1MW-1, MW1-43, MW1-47, MW1-45, and 1MW-4 was reached within 2-5 hours following the low-low in Liberty Bay. All levels are in feet above North American Vertical Datum of 1988. 


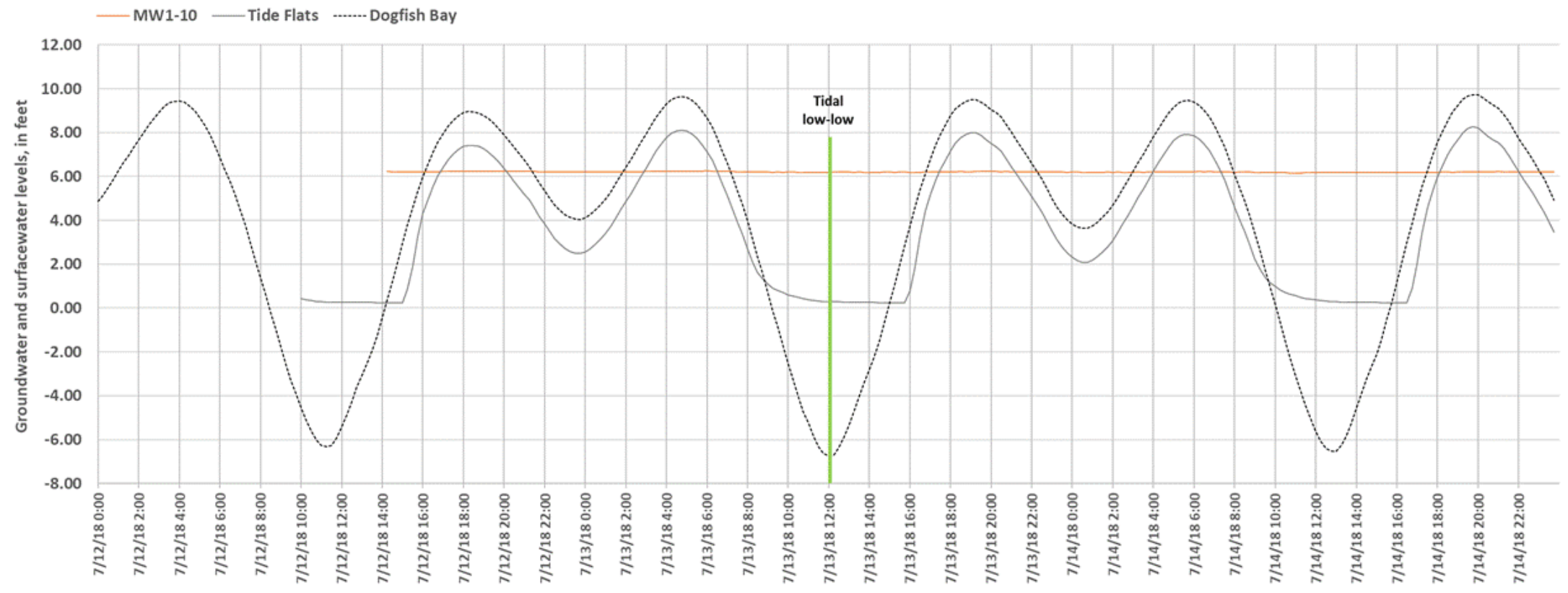

Date and Time (M/DD/YY HH:MM)

Figure 18. Representative graph showing minimal tidal response well group using monitoring well MW1-10 as an example at Operable Unit 1 of Naval Base Kitsap, in Keyport, Washington, July 12-August 14, 2018. Monitoring wells MW1-10, MW1-41, MW1-50, MW1-51, MW1-20, and P1-10 had minimal tidal response. All levels are in feet above North American Vertical Datum of 1988. 


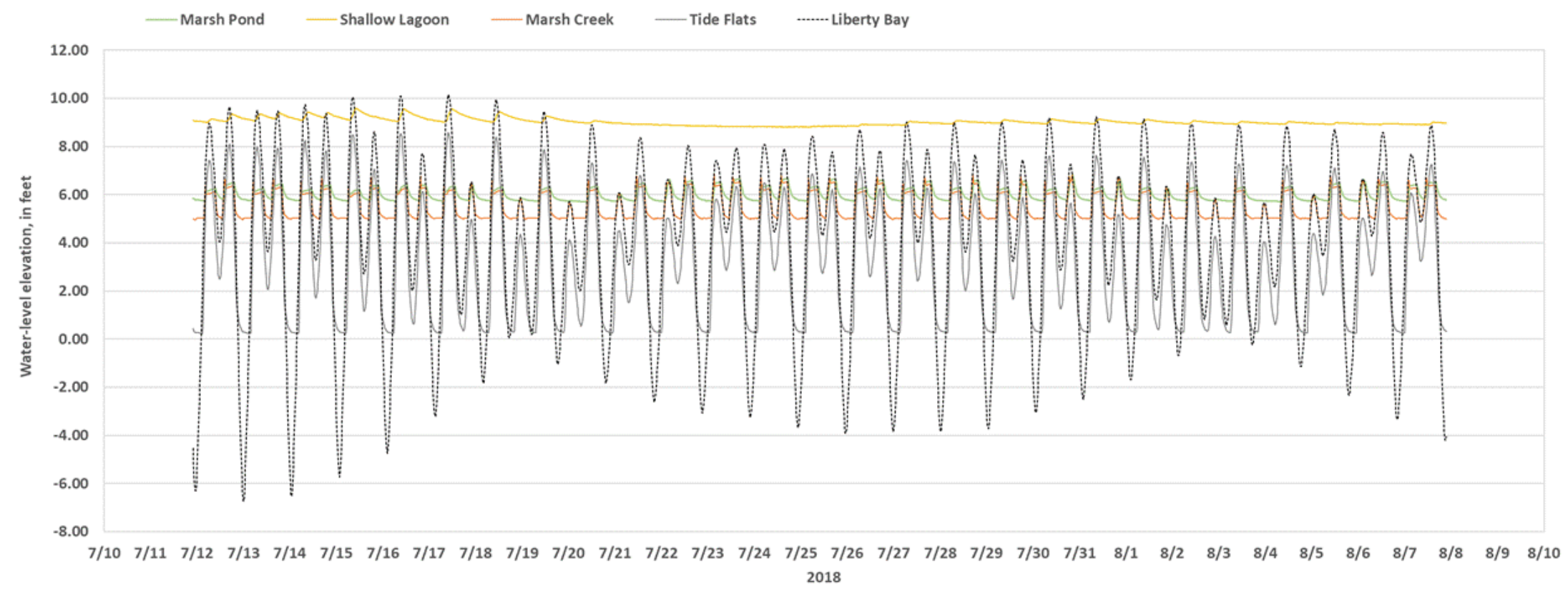

Figure 19. Graph showing surface-water levels measured in Marsh Pond, Shallow Lagoon, Marsh Creek, Tide Flats, and Liberty Bay at Operable Unit 1 of Naval Base Kitsap, in Keyport, Washington, July 12-August 8, 2018. All levels are in feet above North American Vertical Datum of 1988. 


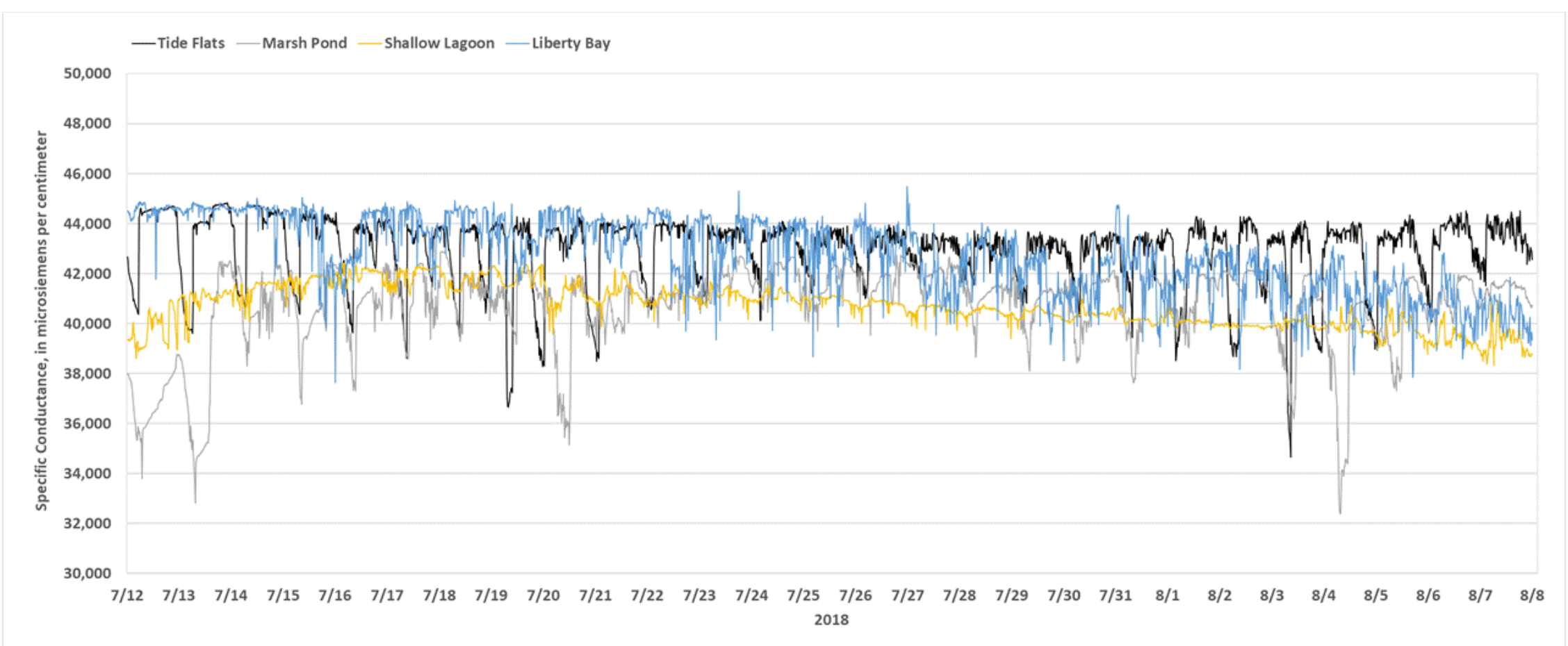

Figure 20. Graph showing specific conductance measured in Marsh Pond, Shallow Lagoon, Tide Flats, and Liberty Bay at Operable Unit 1 of Naval Base Kitsap, in Keyport, Washington, July 12-August 8, 2018. 

Publishing support provided by the U.S. Geological Survey Science Publishing Network, Tacoma Publishing Service Center

For more information concerning the research in this report, contact the Director, Washington Water Science Center

U.S. Geological Survey

934 Broadway, Suite 300

Tacoma, Washington 98402

https://www.usgs.gov/centers/wa-water 


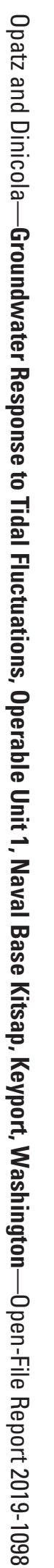

